\title{
Sektör Düzeyinde Rekabet Edebilirlik ve Dünya Talebine Uyum: Türkiye ve Seçili Ülkeler için Bir Analiz*
}

\begin{abstract}
Uğur Aytun ${ }^{1}$
Yılmaz Kılıçaslan²

Sektör Düzeyinde Rekabet Edebilirlik ve Dünya Talebine Uyum: Türkiye ve Seçili Ülkeler için Bir Analiz

Öz

Bu çalışmada seçili on sekiz ülkenin farklı teknoloji yoğunluklarındaki alt endüstrilerinin ticaretinin ihracat payı performanslarını, bunların dünya ticaret payları ile karşılaştırarak görmeye imkân veren Sabit Pazar Payı analizi ile inceledik. 1995-2014 dönemini kapsayan BACl dış ticaret verilerine dayanan bulgular; düşük, orta ve yüksek teknolojili endüstrilerde birçok gelişmekte olan ülkenin pazar paylarını, kendi çabaları, yani rekabet edebilirlik etkisi yoluyla hızlı bir biçimde artırdığını göstermektedir. ABD, Japonya ve Almanya başta olmak üzere, yüksek gelirli ülkeler cephesinde de bu pazar payları ya azalmakta ya da durağan bir konumdadır. Bu iki bulgu küresel değer zincirlerinin yayılması sonucunda üretim sürecindeki birçok aşamanın gelişmiş ülkelerden gelişmekte olan ülkelere kaydığına işaret etmektedir. Öte yandan, Vietnam ve bir dereceye kadar da Çin bu süreçte dünyada talebi artan mallarda da rekabet edebilirliklerini güçlü bir şekilde artırabilmiş ve toplam ihracat bakımından yüksek bir yakınsama

Industry Level Competitiveness and Adaptation to World Demand: An Analysis on Turkey and Selected Countries

Abstract

In this paper, we examined the trade share performance of selected eighteen countries for each sub-sector with different technology intensities by using Constant Market Share analysis which allows to compare these shares with the world trade shares. The findings based on $\mathrm{BACl}$ trade data covering period 1995-2014 showed that most of developing countries in low-, medium-, and high-tech industries rapidly increased their market shares through their attempts called competitiveness effect. Among High-income countries, especially U.S, Japan and Germany, these trade shares have either decreased or been stable position. These two facts imply that many stages of production process in developed countries moved to developing countries due to spreading of global value chains. On the other hand, Vietnam and China, to a lesser extent, were able to improve their competitiveness in the products of which the world demand increase, and thus exhibit a strong convergence performance in total exports.
\end{abstract} performansı gösterebilmişlerdir.

Anahtar Kelimeler: Rekabet Edebilirlik, Sabit Pazar Payı Analizi, SPP, Türkiye, Gelişmekte Olan Ülkeler
Keywords: Competitiveness, Constant Market Share Analysis, CMS, Turkey, Developing Countries

\section{Giriş}

Endüstrilerdeki ticari etkinliğin artırılması, bizi iktisat literatüründeki "rekabet edebilirlik" (competitiveness) kavramına götürür. Kavram sadece iktisat literatüründe değil siyasetçiler ve iş adamları arasında, -yukarıdaki tanımdan farklılıklar gösterse de- sıkça kullanılmaktadır. Ekonomik İşbirliği ve Kalkınma Teşkilatı (OECD) tarafından yapılan ve literatürde sıkça kullanılan tanım: "Rekabet edebilirlik, bir ülkenin, serbest ve adil piyasa şartları altında, uzun dönemde halkın reel gelir düzeyi sürdürülürken ve artırılırken uluslararası rekabet edebilirliği sağlayan mal ve hizmetleri üretebilme derecesidir" biçimindedir (OECD, 1992: 237).

\footnotetext{
*Bu çalışma Eskişehir Anadolu Üniversitesi Sosyal Bilimler Enstitüsü İktisat Anabilim Dalı'nda Doç. Dr. Yılmaz Kılıçaslan danışmanlığında Uğur Aytun tarafından "İmalat Sanayiinde Rekabet Edebilirlik ve Karmaşıklık: Ülkelerarası Bir Analiz" ismiyle tamamlanarak 17.01.2017 tarihinde savunulan doktora tezinden türetilmiştir. Değerli yorum ve katkıları için bu yazının hakemlerine teşekkürü bir borç biliriz.

${ }^{1}$ Arş. Gör. Dr., Ahi Evran Üniversitesi, iiBF, İktisat Bölümü, uguraytun@gmail.com, http://orcid.org/0000-0002-16220046

2 Doç. Dr., Anadolu Üniversitesi, i̇ktisat Fakültesi, íktisat Bölümü, ykilicaslan@anadolu.edu.tr, http://orcid.org/00000003-0222-2259
} 
Porter'a göre ise ekonomilerin bir bütün olarak rekabet edebilir olup olmadıklarını söylemek ve bunu endüstrilerin ürün farklılaştırması, kalite ve teknoloji gibi niteliksel özelliklerini yeterince dikkate almayan ölçütlere (döviz kuru, birim iş gücü maliyeti, doğal kaynak miktarı, dış ticaret dengesi, istihdam oranı, ihracat payı) dayandırmak yanıltıcı olacaktır (Porter 1990: 3-6). Ulusal düzeydeki tanıma eleştiri getiren bir diğer iktisatçı da Lall'dır. O da Porter gibi ulusal ekonominin bir bütün olarak değil de belirli endüstrilerde rekabet edebilir olup olmayacağının tartışılması gerektiğini önermektedir (Lall, 2001a: 1502-1503). Yapılan tanımlar ele alınan birim ve döneme ve bu tanımlara göre kullanılan ölçütler de farklılaşmasına rağmen, ücret düzeyi, döviz kuru gibi kısa dönemli olmayan ve yukarıda bahsedilen endüstriyel faaliyetlerdeki nispi performansın önemini de dikkate alan şu tanımı tercih etmek daha uygun olacaktır (Lall, 2001b s. 67): “Endüstriyel faaliyetlerdeki rekabet edebilirlik sürdürülebilir bir büyüme ile birlikte gelişen nispi etkinliktir. Bu anlamda rekabet edebilirlik nispi anlamda değerlendirilebilecek, mutlak bir durumdan ziyade bir süreçtir."

Bu çalışmada, Türkiye ile seçili ekonomilerin ihracat performansının belirleyicilerini, yukarıda Lall (2001b) tarafından yapılan tanıma da uygun bir biçimde, dünya ticaretinin kompozisyonunda meydana gelen değişimleri de dikkate alarak mikro düzeyde incelenmeye çalışacağız. Bunun için, literatürde sıkça kullanılan Sabit Pazar Payı (SPP) (Constant Market Share, CMS) analizini bölümlendirilmiş (disaggregated) bir yöntemle kullanarak uyguladık. Bu sayede, her bir ülkedeki her bir ana sektörün farklı teknoloji yoğunluklarında dünya piyasasındaki pay değişimlerinin kendi çabalarından mı, o teknoloji yoğunluğuna ait ilgili ana sektörün ürünlerinin o kategoriye ait dünya ticaretindeki payındaki değişimlerden mi, yoksa bu ikisi arasındaki uyumdan mı kaynaklandığını gördük. Literatürde yapılan CMS çalışmalarda ülkelerin toplam ihracat performanslarının kaynakları belirlenmeye çalışılırken, az sayıda çalışma teknoloji yoğunluklarına göre gruplandırmaya giderek benzer metodolojiyi uygulamıştır. Dolayısıyla, burada uygulayacağımız teknoloji yoğunluğu-sektör düzeyindeki ayrıştırma analizimiz daha mikro temellerde bulgular sağlayacak ve daha spesifik politika önermeleri sunacaktır. BACl (2016) verilerini kullanarak, 1995-2014 dönemi için yaptığımız analizler bize Türkiye'nin de dâhil olduğu gelişmekte olan ekonomilerin birçok sektörde dünya piyasalarındaki paylarını hızla artırdıklarını ancak bu süreçte dünyada talebi sabit seyirde olan veya düşen endüstrilerde de payını artırmasının analizdeki uyum etkisini ve bunun sonucunda dünya ticareti payında meydana gelen değişimi olumsuz etkilediğini göstermektedir. Diğer yandan, Vietnam ve daha az ölçüde Çin bu bulgunun önemli ölçüde istisnasını oluşturmaktadır. Bu durum, üretim süreçlerinin dağılması sürecinde bu ülkelerin dünyada talebi artan ürünlerde uzmanlaştıklarını ve bu sayede toplam ihracatları hızlı bir şekilde artırarak diğer ülkelere yakınsayabilmiştir.

Çalışmada öncelikle ele alınan dönemdeki her bir sektörde ve farklı teknoloji yoğunluklarında ticaretin seçili ülkelerde ve dünyada nasıl evrildiğini ikinci bölümde makro bir perspektiften inceleyeceğiz. CMS modelinden ve literatürdeki çalışmalardan ve elde edilen bulgulardan üçüncü bölümde kısaca bahsettikten sonra, dördüncü bölümde kullandığımız CMS modelini ve kullandığımız veri setini tanıtacağız. Beşinci bölümde, geliştirdiğimiz modelin bulgularını sunarak son bölümde bunları yorumlamaya çalışacağız ve birkaç politika önermesi üzerinde duracağı.

\section{Dünya Ticaretine ve Türkiye ile Seçili Ülkelerin İhracat Performansına Genel Bakış}

Dünya ticaretini ve seçili ülkeleri analiz ederken, gerek bu kısımda gerekse daha sonraki kısımlarda Lall (2000)'in teknoloji ve yoğunluğuna göre geliştirdiği ürün sınıflama tablosundan ve 
NACE (Nomenclature of Economic Activities) Rev. 2 Avrupa Topluluğu ekonomik faaliyet sınıflamasından yararlandık. NACE sınıflamasında her bir endüstri içerisine giren ürün grupları o endüstrinin isminden anlaşılabilecekken, teknoloji yoğunluğu sınıflamasında bu durum söz konusu değildir. Bu yüzden, bu sınıflamada imalat sanayiine ait beş kategoriyi aşağıdaki gibi kısaca açıklamakta yarar vardır Lall (2000):

i) Birincil mallar: Bu kategori neredeyse herhangi bir işleme sürecinden geçmemiş ürünleri kapsamaktadır. Tarımsal ürünler (doğal meyveler, pirinç, kakao, çay, kahve), ham petrol, maden (kömür) ve diğer birçok endüstriye girdi sağlayan birçok hammadde (pamuk, lif, odun) bu kategori altında örneklendirilebilir.

ii) Kaynak yoğun ürünler: Buradaki ürünlerin rekabetçi üstünlükleri genel olarak doğal kaynakların erişilebilirliğine bağlıdır ve basit ve emek-yoğun nitelikte ürünlerdir. Ancak bu ürünlerin üretim aşamalarında sermaye, ölçek ve beceri yoğun teknolojilerin kullanılması rekabet edebilirliklerinin sürdürülmesini gündeme getirmektedir. Bu kategorideki ürünlere işlenmiş gıdalar (şeker, peynir, sebzeler), hurda halindeki camlar, optik kablolar, polyesterler, primitif halde plastik ürünler örnek gösterilebilir.

iii) Düşük teknolojili ürünler: Bu gruptaki ürünlerin üretiminde teknoloji sermaye ekipmanları aracılığıyla nüfuz etmektedir ve üretim düşük beceri düzeyi gerektirir. Rekabet genelde işgücü maliyetlerine fiyatlara dayalı iken, bazı düşük teknolojili ürünlerin markalaşma, dizayn ve teknolojik sofistikasyon gibi kaliteye dayalı segmentleri vardır. Ancak gelişmekte olan ekonomilerde kalite rekabetinden ziyade basit teknolojiler hâkimdir ve maliyet ön plandadır. Tekstil sektörü ve bu sektöre girdi sayılabilecek (elyaf, ipek) birçok ürün başta olmak üzere, kuyumculuk, kıymetli madenler (kobalt, magnezyum, berilyum), demir ve çelikten üretilen basit malzemeler (kancalar, vidalar) ve elektrikli ürünler (bataryalar, avizeler), ile saat malzemeleri bu kategori içerisindedir.

iv) Orta düzey teknolojili ürünler: Bu kategorideki ürünler gelişmiş ülkelerdeki endüstriyel faaliyetlerin ana merkezi konumunda olup sermaye ve ara mallarındaki beceri ve ölçek yoğun teknolojileri önemli ölçüde ihtiva eder. Özellikle otomotiv ve mühendislik endüstrileri yüksek düzeyde bağlantı-yoğun (linkage intensive) olduğundan, etkinlik düzeyini en yüksek düzeye çıkarmak için firmalar arasında etkileşim çok yüksek olmaktadır. Doğu Asya ve Latin Amerika'da ihracatın dönüşümünü sağlayan otomotiv, mühendislik (ev aletleri, bazı veri işleme ekipmanları ve baskı devreler) ve süreç ve proses (kimya ve temel metaller) endüstrilerindeki bir çok ürün bu kategoride başlıca endüstriler olurken, ticaretteki payı düşük de olsa petrol endüstrileri arasında sayılabilecek nükleer yakıtlar, yiyecek içecek sektöründe yer alan früktoz, tekstilde akrilik elyaf, ağaç ürünleri, basım ve yayında basılı ürünler ile bazı plastik oyuncaklar de orta teknoloji yoğunluğunda sayılmaktadır.

v) Yüksek teknolojili ürünler: Yüksek Ar-Ge yatırımlarına ve ürün tasarımına öncelik verilen ve çok hızlı teknolojik gelişime maruz kalan ürünler bu gruptadır. Bu teknolojiler karmaşık teknoloji altyapısı, yüksek düzeyde uzmanlaşılan teknik beceri ve firmalar ve firmalar ile araştırma enstitüleri arasında etkileşim gerektirmektedir. Bununla beraber, bu grupta yer alan elektronik sektöründe emek yoğun nihai montaj aşamasına sahip olduğundan, farklı üretim süreçlerinin çok uluslu şirketlerin üretim maliyetlerindeki farklııklara göre ayrıştığı uluslararası entegre üretim sistemlerinin gelişmesine yol açmıştır. Diğer yandan, bu grupta elektronik dışındaki endüstrilerde (havacılık, eczacılık, hassasiyet araçları ve elektrik üretim teçhizatları) üretim halen yüksek düzeyde beceri, teknoloji ve tedarik zincirlerinin olduğu ülkelerde devam etmektedir. Elektronik dışında bebek arabaları ve endüstride kullanılan eldivenler de bu kategori içerisindedir. 
Şekil 1'de yukarıda sözünü ettiğimiz kategorilerin 1990'dan 2014'e kadar dünya ticaretindeki seyri görülmektedir. Buna göre, orta-teknolojili ürünler en yüksek ticaret hacmine sahipken, zamanla bu fark hafif bir eğilimle diğer kategoriler tarafından kapanmaktadır. Tarım sektörünün ve petrol ürünlerinin olduğu birincil mallar kategorisi $2000^{\prime} l i$ yılların ortalarından sonra hızlı bir yükseliş trendine geçmiş ve ikinciliğe yükselmiştir. 1990'lı yılların sonundan itibaren de yüksek teknolojili endüstriler düşük teknolojilileri yakalamış ve son yıllarda birincil mallardan sonra yerini almıştır. Kaynak yoğun ürünler ise 2000 yılına kadar birincil mallar ile benzer seviyelere sahipken, daha sonra bu diğer kategorilerden ayrışmış ve en alt seviyeye gelmiştir.

Şekil 1: Lall (2000) Sınıflamasına göre Dünya Ticareti, 1989-2014

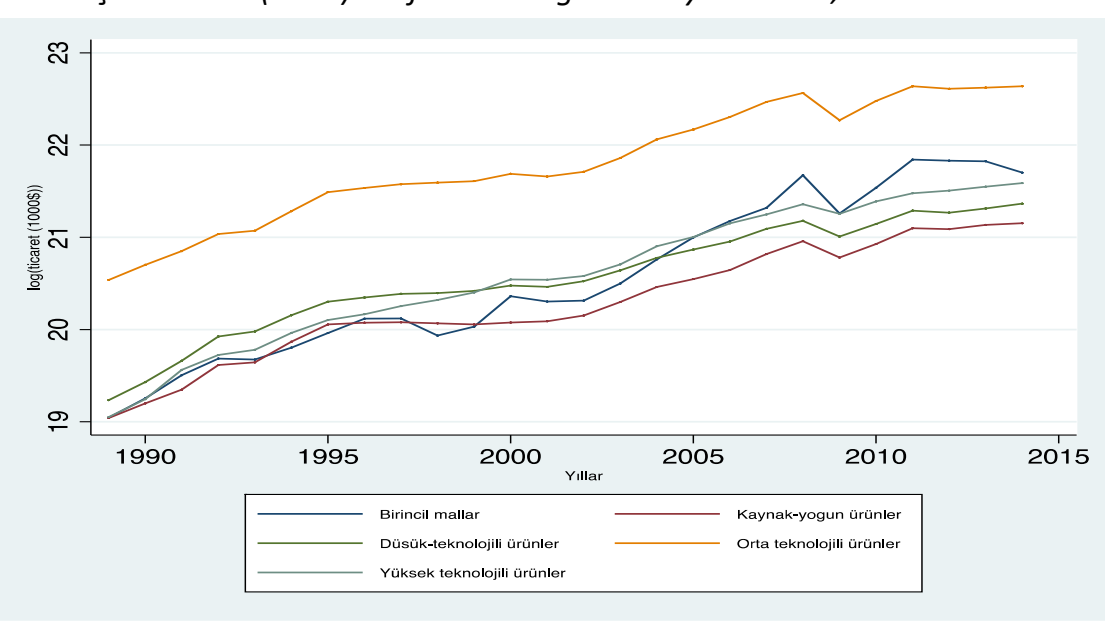

Kaynak: BACI (2016) verileri kullanılarak yazarlar tarafından hesaplanmıştır.

Dünya ticaretinin ana sektörler itibariyle dağılımını da Şekil 2'ten görebiliriz. Madencilik ve petrol sektörünün dönem başında en altlarda yer almasına rağmen, dönem boyunca hızlı bir yükselme gösterdiğini açıkça görerek, yukarıdaki grafiklerde birincil mallardaki yükselişin de kaynağını bizlere işaret etmektedir. Diğer endüstrilerde ise, kimya, fabrikasyon metaller ve

Şekil 2: NACE Rev.2 Ana Sınıflamasına göre Dünya Ticareti, 1989-2014

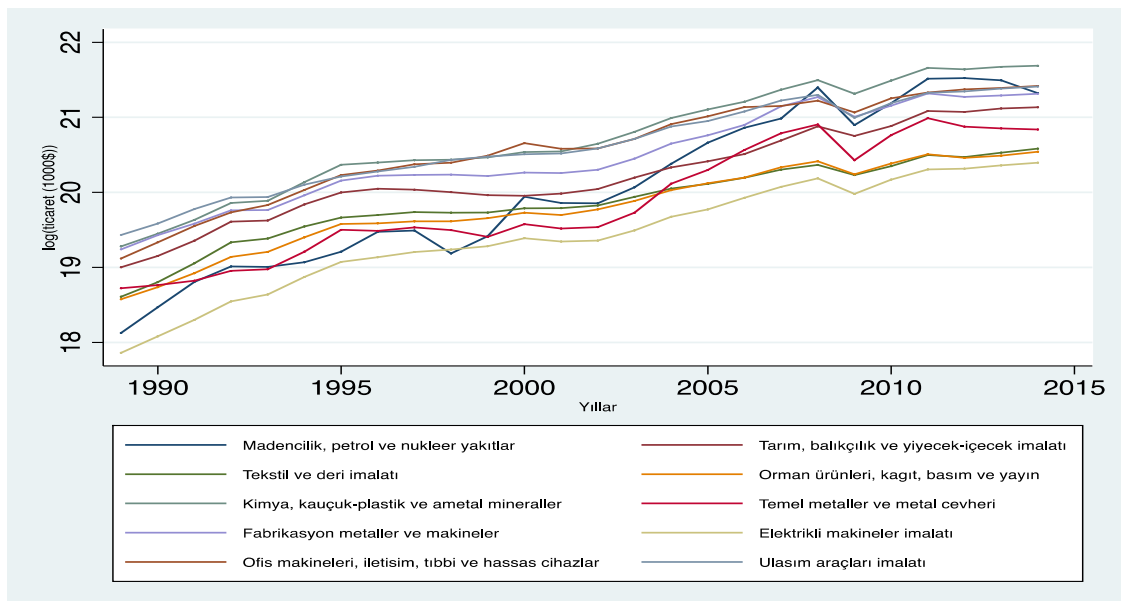

Kaynak: BACI (2016) verileri kullanılarak yazarlar tarafından hesaplanmıştır. 
makineler, ofis makinaları, iletişim hassas cihazlar ve son olarak ulaşım araçlarının dönem boyunca dünya ticaretinde hep üst sıralardadır. Tarım, madencilik, tekstil ve deri, orman ürünleri ve basım-yayın ile elektrikli makineler dünya ticaretinde daha az yer kaplayan ana endüstriler olarak karşımıza çıkmaktadır.

Toplulaştırılmış istatistiklere, seçili ülkelerin toplam ihracatları cinsinden bakacak olursak, Çin, ABD, Almanya, Japonya ve bir dereceye kadar Güney Kore'nin ele aldığımız diğer ülkelerden ayrıştıklarını, Şekil 3'e bakarak görebilmekteyiz. Bu yüksek ihracat yapan ülkeler arasında özellikle 2000 yılından sonra Çin'in performansı oldukça çarpıcıdır. Diğer yüksek ihracat yapan ülkeler ise daha yatay pozisyonda konumlarını sürdürmektedirler. Diğer gruptaki ülkeler arasında da karşımıza ilk çıkan ülke, dönem başında oldukça düşük ihracat seviyesine sahip olan ancak daha sonra bu gruptaki ekonomilere katılan Vietnam'dır. Grubun başka üyeleri de, Şili ve Filipinler hariç, daha yatay bir seyir izlediklerinden son yıllara doğru birbirlerine doğru yaklaşmaktadırlar (Bk. Şekil 3). Türkiye ise gelişmekte olan ülkelere benzer bir yükseliş trendi gösterebilmiştir.

Şekil 3: Türkiye ile Seçili Ülkelerin Toplam ihracatı, 1989-2014

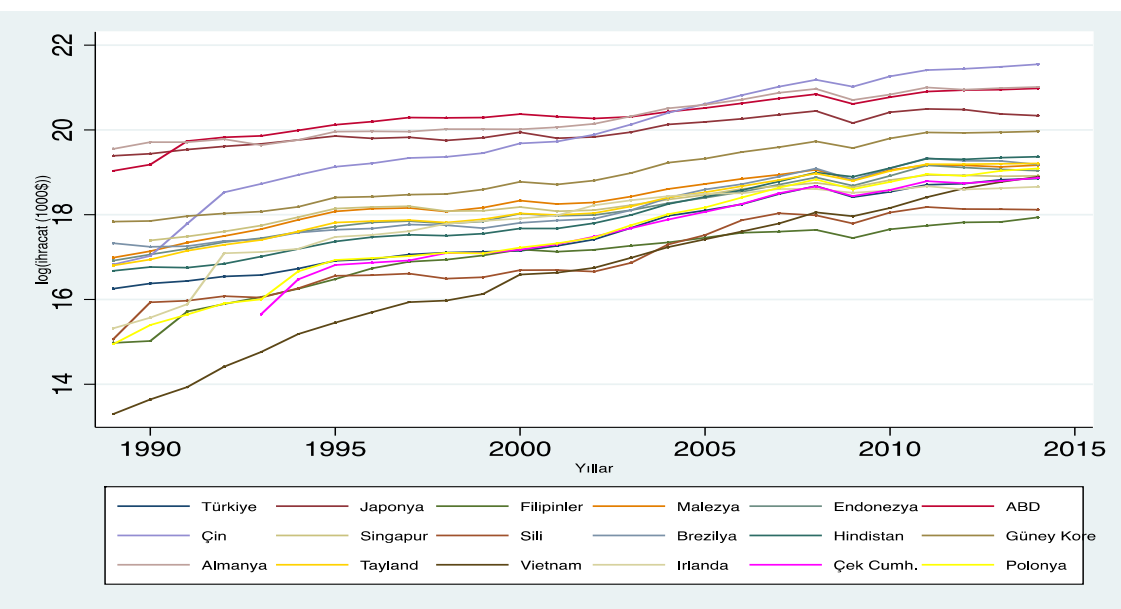

Kaynak: BACl (2016) verileri kullanılarak yazarlar tarafından hesaplanmıştır.

Aşağıdaki bölümlerde, Şekil-3'te gördüğümüz gelişmiş ve gelişmekte olan ülkelerdeki toplam ihracat performansının, Şekil-1 ve Şekil-2'de gördüğümüz dünyadaki ticaret eğilimleri ile ilişkisini, her bir teknoloji kategorisi altındaki ana endüstriler itibariyle irdelemeye çalışacağız.

\section{Sabit Pazar Payı Analizi Metodolojisi ve Bununla ilgili Yürütülen Ampirik Çalışmalar}

Sabit pazar payı (CMS) analizi, bir ülkenin başka bir ülkeye, bölgeye veya dünyaya, bir mal grubu veya tüm mallara ilişkin ihracatının payında meydana değişimi "yapısal" ve "rekabet edebilirlik" olmak üzere farklı bileşenlere ayırabilmemize olanak sağlamaktadır. Bu ayrıştırma sayesinde söz konusu ülkenin belirli bir üründe veya belirli bir coğrafi piyasada pazar payını korumasına veya azalmasına rağmen, toplam ihracatının dünya ticareti içerisindeki payını hangi etmenlerden dolayı artırdığı veya azalttığı gözlemlenebilmektedir. Literatürde ilk olarak Tyszynski (1951: 288) tarafından kullanılan analiz yöntemine göre bir ekonominin belirli bir endüstrideki ihracatının partner ülkenin toplam ithalatı içerisindeki payında meydana gelen değişim dünya ticareti ve rekabet edebilirlik olmak üzere iki etmene ayrılmaktadır. Tyszynski (1951: 297)'nin 1899-1950 yılları arasında 11 gelişmiş ekonomi için yaptığı çalışmada dış ticarete söz konusu 
imalat sanayii endüstrileri 16 gruba ayrılmıştır. Bulgulara göre farklı ürün gruplarında rekabetçi konumunu güçlendirerek dünya ticaretindeki ağırlı̆̆ını en fazla artıran ülkeler sırasıyla Amerika Birleşik Devletleri (ABD), Japonya ve Kanada'dır. Daha sonra bu model Baldwin (1958) ve Spiegelglas (1959) tarafından da kullanılmıştır.

Tyszynski (1951)'nin kullandığı iki faktörlü sabit pazar payı analizi daha sonra Leamer ve Stern (1970: 172-175) tarafından geliştirilmiştir. Pay değişkenleri yerine miktar değişkenlerinin kullanıldığı modelde bir dönem boyunca ihracattaki değişim üç faktörce açıklanmaktadır. Bunlardan ilki mal bileşimi etkisidir. İhracatın, uluslararası piyasalarda talep artışı yüksek mallarda ne kadar uzmanlaştığını temsil etmektedir. İhracat miktarını etkileyen bir diğer faktör ise piyasa dağılımı etkisidir. Ekonominin ihraç ettiği malların ne derece ithalat talebi yüksek olan piyasalarda yoğunlaştığını göstermektedir. İhracatı etkileyen son faktör olan rekabet edebilirlik etkisi bu modelde söz konusu ekonominin n ülkesine ihraç ettiği i malının pazar payının artışı ya da azalışıdır. Diğer faktörlerden farklı olarak rekabet edebilirlik etkisi bu modelde yalnızca ihraç mallarının fiyat düzeyiyle ilişkilendirilmektedir.

Leamer ve Stern (1970)'in geliştirdiği üç faktörlü modelin ampirik uygulamasını ilk yapanlar arasında Banerji (1974), Bowen ve Pelzman (1984), ve Merkies ve Meer (1988) gösterilebilir. Banerji (1974: 475)'nin 16 ülke için yürüttüğü çalışma gelişmekte olan ekonomilerin büyük ölçüde uluslararası talebinin yavaş büyüdüğü mal ve piyasalara odaklandığını ve bunun ihracat miktarında yavaşlamaya neden olduğunu ampirik olarak göstermektedir. Bowen ve Pelzman (1984) ise, Richardson (1971a, 1971b)'ın Leamer ve Stern'in (1970) modeline getirdiği eleştirileri de test ettiği çalışmalarında ABD'nin 1962-1977 döneminde rekabet gücünde azalma tespit etmiş ve bunu aynı dönemdeki ihracat malları fiyatları artışının diğer ülkelere göre düşük kalmasına bağlamıştır. Merkies ve Meer (1988: 77-78) de 1972-1976 döneminde, Asya ve Pasifik Komisyonu (ESCAP) ABD ve diğer ülkeler arasında, imalat sanayiindeki beş kategorinin dikkate alındığı çalışmada piyasa dağılımı etkisinin en yüksek Endonezya'ya, en düşük ise diğer kategorisindeki ülkelere ait olduğu görülmektedir. Mal bileşimi bileşeni için, petrol ihracatçısı olmayan ülkeler arasında $A B D$ en yüksek değere, Filipinler en düşük değere sahiptir. Son olarak, rekabet edebilirlik bileşeninde önemli ölçüde farkla Kore birinciyken, İran en sonda yer almaktadır.

Richardson (1971a, 1971b)'un bu model ile ilgili getirdiği eleştiriler (özellikle endeks numarası ve etkilerin hesaplanma sırası problemleri) literatürde Fagerberg ve Sollie (1987) tarafından dikkate alınarak beş etkiye sahip sabit pazar payı modeli geliştirilmiştir. Gösterge sayısı probleminin çözümü için Laspeyres indislerinin kullanılmasıyla ortaya çıkan artık terimler, mal bileşiminde ve pazardaki değişimlere uyumu gösteren daha dinamik bir rekabet edebilirlik etkisini temsil eden bir modelin ortaya çıkmasını sağlamıştır. Bu yeni CMS modeli yukarıda bahsedildiği gibi kurgulandıktan sonra 1961-1983 yılları dönemi ele alınarak 20 OECD ülkesi için uygulanmıştır. Bulgular OECD ticaretinde meydana gelen yapısal değişimlerin oldukça önemli olduğuna işaret etmektedir. Ayrıca gelişmiş ekonomilerin uyum potansiyelinin diğer OECD ekonomilerine göre daha az olduğu tespit edilmiştir (Fagerberg ve Sollie, 1987: 1580-1581). Modelin bir başka uygulaması da OECD (1996: 111-114) tarafından yürütülmüş, 24 üye ülkenin 1980-1993 yılları arasındaki ihracat performansı analiz edilmiştir. Sonuçlar ilk bakışta ihracat paylarında artışlar yaşayan ülkelerin -özellikle Türkiye, İspanya, Portekiz, İrlanda- bunu büyük ölçüde bireysel endüstriler içerisindeki piyasa payı etkileri aracılığıyla sağladıklarını göstermektedir. Küçük ölçekli ekonomiler için ise ihracat payındaki azalmanın en önemli kaynaklarından birisi mal bileşimi etkisidir. Öte yandan başlangıç mal bileşimi ve piyasa dağılımı bileşenleri dezavantajlı durumda olan Yunanistan ve Türkiye gibi ülkelerin de geleneksel sektörlerindeki ihracat paylarında ele 
alınan dönem boyunca azalma tespit edilmiştir. Son olarak çalışmada uyum etkileri konusunda, Türkiye'nin her iki bileşende güçlü negatif değerlere sahip olduğu ve bunu piyasa payı etkisiyle önemli ölçüde telafi ettiği görülmüş ve vurgulanmıştır. Yukarıda Fagerberg ve Sollie (1987) modelinin uyum etkileri, mekânsal uyum bileşenleri çıkarılarak Laursen (1999: 348) tarafından yeniden uyarlanmıştır. Bizim de bu bölümde uygulayacağımız modelde uyum etkisi, "büyüme uyumu etkisi" ve "durağanlık uyumu etkisi" olmak üzere iki bileşene ayrılmıştır.

Türkiye ekonomisi için yapılan sabit pazar payı analizlerinde ilk olarak Ongun (1990)'dan bahsedilebilir. Hem Leamer ve Stern (1970)'in ve Fagerberg ve Sollie (1987)'nin tekniklerinin hem de miktar ve değer verilerinin uygulandığı çalışmasında 1976-1987 dönemleri arasında Türkiye'nin Avrupa Topluluğu ekonomilerindeki sebze ve meyve ihracatı performansı analiz edilmiştir. Her iki teknikle ve her iki veri tipiyle farklı bulgular elde edilmesine rağmen pazar payı etkisi tüm durumlarda negatif bulunmuştur. Ayrıca, mal adaptasyonu etkisi pozitif, piyasa adaptasyonu etkisi ise negatif çıkmıştır. Bu durum Türkiye'nin Avrupa Topluluğu pazarında doğru ürünler ihraç edebilirken, bu ürünleri doğru piyasalara yöneltmede başarısız olduğunu göstermektedir.

Kotan (2000) tarafından yapılan çalışma da Türkiye'deki tüm ihraç ürünlerini kapsamaktadır. Leamer ve Stern (1970)'in yaklaşımının uygulandığı çalışmada Türkiye ve Güney Doğu Asya ülkelerinin Avrupa Birliği pazarındaki ihracat performansları kıyaslanmış ve Türkiye'nin piyasaya coğrafi yakınlığının rekabet edebilirliğe bir katkısının olup olmadığı araştırıımıştır. Bulgular Türkiye'nin coğrafi yakınlık sayesinde fiyat cinsinden (özellikle tekstil, giyim eşyası ve teknoloji yoğun sektörlerde) göreli bir avantaja sahip olduğunu göstermektedir.

Lohrmann (2000) Türkiye'nin 1980'den sonra geçirdiği yapısal dönüşüm sürecinde ihracat performansını Fagerberg ve Sollie (1987)'nin modelinden yararlanarak analiz etmiştir. Analiz sonuçları 1980 sonrasında Türkiye'nin dünya ihracat pazarındaki payında önemli artışlar görülmekle birlikte OECD piyasalarının değişen talep yapısına iyi bir şekilde uyum sağlayamadığını göstermektedir.

Türkiye için Leamer ve Stern (1970)'in yaklaşımıyla yapılan bir başka çalışma da Temiz (2002) tarafından yürütülmüştür. Richardson (1971a, 1971b)'ın modele yaptığı eleştirilerin de göz önünde bulundurulduğu analizde Türkiye'nin 1989 ile 1998 dönemleri arasında tarım ürünleri ihracatı performansı hem değer hem de miktar verileri ile ölçülmeye çalışılmıştır. Sonuçlara göre Türkiye mal bileşimi ve pazar dağılımı etkileri yönünden iyi bir konumdadır, yani "doğru" ürünleri "doğru" pazarlarda satabilmektedir. Bununla beraber, Türkiye'nin tarım ürünlerinde değer cinsinden elde edilen rekabet edebilirliği, ihracat yaptığı ekonomilerdeki ihracat paylarını zaman içerisinde sürdürememesinden dolayı negatif olarak hesaplanmıştır. Bu durum Türkiye'nin rekabet edebilirlik sorununun talep kaynaklı olmadığını göstermektedir.

Tatarer (2004: 57-58) de Fagerberg ve Sollie (1987)'nin yaklaşımından yararlanarak 19922002 döneminde 261 imalat sanayii endüstrisi için Türkiye'nin Doğu Asya piyasalarındaki ihracat performansını analiz etmiştir. Analizden elde edilen bulgular Türkiye'nin ihracat yapısı için söz konusu dönemde pazar payı etkisinin hâkim olduğunu göstermektedir. Etkisi en az olan bileşen ise mal bileşimine uyum etkisidir. Ancak bu etkinin Japonya ve Kore için pozitif bulunması, Türkiye'nin ihracatını bu ülkelerin ithalat yapısına göre yönlendirebileceğine işaret etmektedir.

Yine Leamer ve Stern (1970)'in modeline benzer bir analiz Klasra ve Fidan (2007: 326-328) tarafından yapılmıştır. Belirli ülkelerin balık ürünleri ihracat paylarında rekabet gücünün ölçül- 
mesi amacıyla oluşturulan modelde Laspeyres ağırlıklarının kullanılmasıyla dört etki daha ortaya çıkmıştır. Sabit pazar payı analizi sonuçları, pozitif piyasa dağılımı terimine sahip Türkiye'nin talebi artan piyasalarda ihracat yapmayı hedeflediğini, fakat Danimarka, Hollanda ve Türkiye'nin rekabet edebilirliği en düşük ülkeler olduğunu ve "yapısal artık" teriminin ihracata negatif katkı yapmaya devam ettikçe daha da azalacağını göstermektedir.

Şahan (2012: 86-87) tarafından yürütülen bir çalışmada da üçüncü düzey imalat sanayii endüstrilerine ait ihracat verileri kullanılarak sabit pazar payı analizi yapılmıştır. Fagerberg ve Sollie'nin (1987) modelinin Laursen (1999) tarafından geliştirildiği metodolojiden yararlanılan çaIışmada 2003-2008 döneminde Türkiye'nin endüstrilerdeki ihracat paylarında meydana gelen önemli değişmelerin yapısal piyasa etkisinden kaynaklandığı görülmüştür. Ayrıca sektörlerin teknolojik yoğunluklarına göre kategorileştirildiği durumda ilgili dönem boyunca yüksek teknolojili endüstrilerin toplam ihracata pozitif katkı sağlandığı gözlenmektedir.

Son olarak, Erlat ve Erlat (2012: 11) Fagerberg ve Sollie (1987)'nin metodolojisini endüstrileri toplulaştırarak kullanmışlar ve Türkiye'nin Orta Doğu ülkelerindeki performansını analiz etmişlerdir. Bu toplulaştırma işlemi sonucunda modelin üç bileşene indirgendiği çalışmaya göre, Türkiye'nin bu ülkelerdeki ihracat payının düşmesindeki en büyük etken mal bileşimine uyum terimidir. Bu durum Türkiye'nin bu ülkelerde değişen talep kompozisyonlarına gerekli uyumu sağlayamadığı şeklinde yorumlanabilir.

Aşağıdaki metodolojide, yukarıdakilerden farklı olarak ticarete konu olan tüm sektörleri içermekle birlikte, aynı zamanda CMS bulguları toplulaştırılmış değil, her bir teknoloji yoğunluğu altında yer alan sektörler için sunulacaktır. Dahası, Larsson (1999) modelinin kullanılması, ülkelerin rekabet edebilirliklerini değiştirirken dünya talebine göre uyumlu olup olmadığını görmemize yardımcı olacaktır. Bu sayede, ülkelerin hangi sektörlerde rekabet edebilirliğini artırırken bunun dünyada payı artan bir endüstri olup olmadığını görmemize imkân tanımaktadır.

\section{Kullanılan Model ve Veri}

Yukarıdaki literatür ışı̆̆ında, çalışmada ticaretin mekânsal özelliklerini elimine ederek, dünya piyasalarına uyum etkilerini daha ayrıntılı görebilmek ve bunları yorumlayabilmek amacıyla, Laursen (1999)'in modelini kullanmaya karar verdik. Bu modele göre, bir ülkenin, belirli bir ürün grubuna ait dünya ticareti içerisindeki ihracat payındaki iki dönem arasındaki yüzdelik değişim (toplam değişim, TD), ülkenin bu ürünlerdeki ihracatının dünya ticaretindeki paylarının ayrı ayrı kendi çabalarından dolayı meydana gelen değişimden (rekabet edebilirlik etkisi, RE), bu ürünlerin dünya ticaretindeki payındaki değişimden (mal bileşimi etkisi, MBE) ve ülkenin bu ürün grubundaki ihracatının dünya ticareti içerisindeki payındaki değişimin, ürünlerin dünya ticaretindeki değişim ile aynı yönlü olup olmamasından (toplam uyum etkisi, TUE) kaynaklanmaktadır. Ayrıca, son etki de ülkenin dünyada talebi artan mallara doğru ticaret payını artırma (büyüme uyumu etkisi, BUE) ve dünyada talebi azalan mallarda ticaret payını azaltabilme (durağanlık uyumu etkisi, DUE) kabiliyetini göstermek üzere iki bileşene daha ayrılmaktadır.

$i$ ve $t$ alt indisleri sırasıyla bu ürün grubuna ait ürün grubu içerisinde yer alan tekil ürünler ve zaman, $m$ üst indisi de ihracat yapan ülkeyi ve son olarak da $X$ de parasal değer cinsinden ihracat miktarını göstermek üzere, bu model aşağıdaki gibi yazılabilir:

$$
\underbrace{\Delta\left(\frac{\sum_{i} X_{i t}^{m}}{\sum_{m} \sum_{i} X_{i t}^{m}}\right)}_{T D}=\underbrace{\sum_{i} \Delta\left(\frac{X_{i t}^{m}}{\sum_{m} X_{i t}^{m}}\right) *\left(\frac{\sum_{m} X_{i t}^{m}}{\sum_{m} \sum_{i} X_{i t}^{m}}\right)}_{R E}+\underbrace{\sum_{i}\left(\frac{X_{i t}^{m}}{\sum_{m} X_{i t}^{m}}\right) * \Delta\left(\frac{\sum_{m} X_{i t}^{m}}{\sum_{m} \sum_{i} X_{i t}^{m}}\right)}_{M B E}
$$




$$
\underbrace{+\sum_{i} \Delta\left(\frac{X_{i t}^{m}}{\sum_{m} X_{i t}^{m}}\right) * \Delta\left(\frac{\sum_{m} X_{i t}^{m}}{\sum_{m} \sum_{i} X_{i t}^{m}}\right)}_{T U E}
$$

Diğer bir deyişle ifade edecek olursak, yukarıdaki eşitlikte de görüleceği gibi, her bileşendeki ilk terim ülkenin ilgili tekil malın toplam dünya ticareti içindeki ihracat payını, diğeri de o ürün grubunun dünya ticareti içerisinde tekil malın ticaret payını göstermektedir. Son olarak, eşitlikteki son ifade olan TUE de şu iki bileşene ayrılarak ülkelerin dünya ticaretinde paylarını değiştirirken bu ürünlerin ticaret paylarındaki değişime göre yapıp yapmamasına göre ne kadar uyumu olduğunu daha iyi görmemize yardımcı olmaktadır:

$$
\begin{aligned}
\underbrace{\sum_{i} \Delta\left(\frac{X_{i t}^{m}}{\sum_{m} X_{i t}^{m}}\right) * \Delta\left(\frac{\sum_{m} X_{i t}^{m}}{\sum_{m} \sum_{i} X_{i t}^{m}}\right)}_{T U E} & =\underbrace{\sum_{i} \Delta\left(\frac{X_{i t}^{m}}{\sum_{m} X_{i t}^{m}}\right) *\left(\Delta\left(\frac{\sum_{m} X_{i t}^{m}}{\sum_{m} \sum_{i} X_{i t}^{m}}\right)+\frac{\left|\Delta\left(\frac{\sum_{m} X_{i t}^{m}}{\sum_{m} \sum_{i} X_{i t}^{m}}\right)\right|}{2}\right)}_{B U E} \\
& +\underbrace{\sum_{i} \Delta\left(\frac{X_{i t}^{m}}{\sum_{m} X_{i t}^{m}}\right) *\left(\Delta\left(\frac{\sum_{m} X_{i t}^{m}}{\sum_{m} \sum_{i} X_{i t}^{m}}\right)-\frac{\left|\Delta\left(\frac{\sum_{m} X_{i t}^{m}}{\sum_{m} \sum_{i} X_{i t}^{m}}\right)\right|}{2}\right)}_{\text {DUE }})
\end{aligned}
$$

Yukarıdaki CMS eşitliklerinin hesaplanmasında, CEPII tarafından 1989-2014 dönemini kapsayan ve altı haneli uyumlaştırılmış sistem (harmonized system, HS) sınıflaması kapsamında derlenen BACl (2016) dış ticaret verilerinden yararlandık. Bu altı haneli ürün sınıflamasını yukarıda da bahsettiğimiz Lall (2000)'nin teknoloji sınıflamasındaki her bir NACE Rev 2 ana sektörü için grupladık. Bu sayede beş teknoloji kategorisi için toplam 38 ürün grubu elde etmiş olduk. Ancak her ürün grubunu ayrı ayrı incelemek yerine, her bir teknoloji kategorisinin dünya ticaretinde en çok paya sahip ürün gruplarını ele aldık. Nitekim aşağıdaki bulgular dünya ticaretinin \%76'sına denk gelen 11 ürün grubuna aittir. Seçili ülkeler ise farklı coğrafi bölgelerde, gelişmekte olan ve mamul ürün ihracatına dayalı olarak büyümeye çalışan ülkeler yanında ${ }^{3}$, kıyaslama yapabilmek amacıyla endüstriyel gelişimini tamamlamış ve yüksek düzeyde ihracat yapan beş ülkenin de dâhil olduğu toplam 18 ülkeyi içermektedir ( $A B D$, Almanya, Japonya, Güney Kore, Singapur).

\section{Bulgular}

Birincil mallar içerisinde yer alan madencilik, petrol ve nükleer yakıtlar endüstrilerine ait seçili ülkelerin CMS bulguları Tablo 1 verilmektedir. Buna göre, çoğu ülkede ilgili dönemde toplam değişimi belirleyen en önemli faktör rekabet edebilirlik etkisidir. Bu bileşen, Türkiye ve Brezilya'nın payında meydana gelen büyük sıçramaya katkı sağlarken, Çek Cumhuriyeti, İrlanda, Polonya, Çin, Hindistan ve Tayland'daki önemli pay kayıplarının başlıca nedeni olmuştur. Diğer bileşenler itibariyle incelediğimizde, İrlanda'nın mal bileşimine uyum etkisi (MBE) seçili ülkeler arasında en düşük durumdadır. Bir diğer deyişle, i̇rlanda'nın bu ürünlerdeki uzmanlığına göre ağılıklandırılmış dünya talebi azalmış ve bu ticaret payını önemli ölçüde olumsuz etkilemiştir. Bu bileşenden \%1'in üzerinde ticaret payı kazanan bir ülke yoktur. Uyum etkilerinde de benzer

\footnotetext{
${ }^{3}$ Gelişmekte olan seçili ülkeler, bulundukları bölgelerdeki (Güneydoğu Asya, Avrupa, Amerika) merkez ülkelerin üretim süreçlerinin üretim süreçlerinin kendilerine kaydığı ve bu sebeple daha dışa açık yapıya sahip ülkeler oldukları için örneklemimize dâhil edilmişlerdir.
} 
bir durum söz konusudur. Toplam uyum etkisinde yalnızca İrlanda ve Brezilya'nın değeri \%1'in üzerindedir. Ancak İrlanda'nın bu performansı DUE'den kaynaklanırken, Brezilya BUE aracılığıyla bu uyumunu artırmıştır. Yani İrlanda dünyada payı düşen ürünlerden başarılı bir şekilde çıkarak, Brezilya da başarılı bir şekilde dünyada payı artan sektörlerde payını artırarak toplam ticaret payına katkı sağlamıştır. Türkiye ise bu ürünlerdeki payını yalnızca RE etkisiyle artırmış, dünyada talebi artan ürünlere doğru uyum performansı zayıf kalmıştır.

Tablo 1: Birincil Mallar Kategorisinin Madencilik, Petrol ve Nükleer Yakıtlar Endüstrilerinde Seçili Ülkelerin CMS Analizi Bulguları, 1995-2014

\begin{tabular}{lrrrrrr}
\hline Ülke & RE (\%) & MBE (\%) & BUE (\%) & DUE (\%) & TUE (\%) & \multicolumn{1}{c}{ TD (\%) } \\
\hline ABD & 0.65 & -1.66 & 0.14 & 0.65 & 0.80 & -0.20 \\
Almanya & -0.71 & -0.63 & 0.45 & 0.50 & 0.95 & -0.00 \\
Çek Cumhuriyeti & -3.95 & -0.71 & -0.48 & 1.01 & 0.53 & -4.13 \\
Güney Kore & 1.83 & -0.99 & 0.10 & -0.53 & -0.42 & 0.41 \\
Irlanda & -2.16 & -3.17 & 0.00 & 1.35 & 1.35 & -3.99 \\
Japonya & 3.70 & -0.69 & -0.01 & -2.37 & -2.39 & 0.61 \\
Polonya & -4.31 & -1.58 & -0.01 & 1.36 & 1.34 & -4.54 \\
Şili & 2.22 & -0.02 & 0.00 & -0.45 & -0.45 & 1.74 \\
Singapur & -1.89 & -0.38 & -0.02 & -0.56 & -0.58 & -2.86 \\
Brezilya & 150.42 & -0.00 & 2.05 & 0.01 & 2.07 & 152.48 \\
Çin & -4.45 & -0.61 & 0.00 & 0.45 & 0.45 & -4.61 \\
Endonezya & -2.44 & 0.44 & -0.44 & -.027 & -0.72 & -2.72 \\
Filipinler & 0.11 & -0.82 & 0.04 & 0.83 & 0.88 & 0.16 \\
Hindistan & -3.83 & 0.52 & -0.81 & 0.09 & -0.71 & -4.03 \\
Malezya & -1.41 & 0.43 & 0.12 & 0.18 & 0.31 & -0.66 \\
Tayland & -4.12 & 0.48 & -0.89 & 0.31 & -0.58 & -4.21 \\
Türkiye & 34.35 & -1.97 & 0.40 & -1.27 & -0.87 & 31.50 \\
Vietnam & -0.55 & -0.02 & -0.00 & -0.01 & -0.02 & -0.60 \\
\hline
\end{tabular}

Kaynak: BACI (2016) verileri kullanılarak yazarlar tarafından hesaplanmıştır.

Tarım, balıkçılık ve yiyecek-içecek endüstrilerinin CMS bulgularını incelediğimizde, Tablo 1'de olduğu gibi RE bileşeninin toplam değişimde önemli bir yere sahip olduğunu Tablo 2'den görebiliriz. Yani bu seçili ülkelerdeki pay değişimlerinin büyük bir bölümü kendi çabalarından kaynaklanmaktadır. Vietnam, Hindistan, Çin, Brezilya, Şili ve Polonya ve Çek Cumhuriyeti pazar paylarını önemli ölçüde artırmışlar, ancak bunlar arasında Brezilya talebi artan endüstrilere de yoğunlaşarak uyum etkisi sayesinde payını daha da artırabilmiştir. Bu ülkeler arasında Polonya ve Vietnam esasında dünyada talebi artan mallara doğru kendi dünya pazar paylarını uyumlu bir biçimde artırmışlar, ancak bu pazar paylarındaki artış dünyada talebi düşen mallarda da gerçekleştiği için uyum performansını olumsuz etkilemiş, dolayısıyla toplam Pazar payını azaltmıştır. Şili ise hem MBE hem de TUE sayesinde pazar payını artırmıştır. Payı dönem boyunca azalan 
ülkelerde de gerek MBE gerekse de TUE bileşenleri ABD dışında zayıf kalmıştır. Bu ürünlerde, incelenen dönemde, Türkiye'nin Dünya ticaret payında çok önemli bir değişme olmamış (\%0.53) ve neredeyse her bileşendeki değerleri \%1'in altında kalmıştır. Bu gelişmenin aslında çok kötü olduğunu söyleyemeyiz. Payı dönem boyunca azalan ülkelerde de gerek MBE gerekse de TUE bileşenleri $A B D$ dışında zayıf kalmıştır. MBE'nin tüm seçili ülkelerde düşük değerlere sahip olması bu endüstrilerin artık dünya ticaretinde bu ürün grubunun payını artıramadığına işaret etmektedir.

Tablo 2: Birincil Mallar Kategorisinin Tarım, Balıkçılık ve Yiyecek-içecek Endüstrilerinde Seçili Ülkelerin CMS Analizi Bulguları, 1995-2014

\begin{tabular}{|c|c|c|c|c|c|c|}
\hline Ülke & RE (\%) & MBE (\%) & BUE (\%) & DUE (\%) & TUE (\%) & TD (\%) \\
\hline$A B D$ & -2.05 & 1.02 & -0.60 & 0.22 & -0.38 & -1.41 \\
\hline Almanya & 0.12 & -0.31 & -0.05 & 0.10 & 0.05 & -0.13 \\
\hline Çek Cumhuriyeti & 3.42 & -0.80 & 0.13 & -0.78 & -0.64 & 1.98 \\
\hline Güney Kore & -2.60 & -1.06 & -0.14 & 0.81 & 0.66 & -3.01 \\
\hline İrlanda & -2.31 & -0.53 & -0.24 & 0.42 & 0.18 & -2.67 \\
\hline Japonya & -1.03 & -0.25 & -0.32 & 0.11 & -0.21 & -1.50 \\
\hline Polonya & 11.45 & 0.31 & 2.33 & -1.51 & 0.82 & 12.59 \\
\hline Şili & 0.92 & 1.13 & 1.24 & 0.10 & 1.34 & 3.40 \\
\hline Singapur & -3.97 & -0.67 & -0.61 & 1.16 & 0.55 & -4.09 \\
\hline Brezilya & 7.36 & 0.37 & 4.02 & -1.34 & 2.68 & 10.41 \\
\hline Çin & 2.33 & 0.52 & -0.07 & -0.30 & -0.38 & 2.47 \\
\hline Endonezya & -0.67 & -0.38 & -0.13 & 0.06 & -0.07 & -1.12 \\
\hline Filipinler & 1.24 & 0.01 & -0.22 & -0.69 & -0.91 & 0.34 \\
\hline Hindistan & 5.97 & 0.45 & 0.22 & -1.74 & -1.52 & 4.90 \\
\hline Malezya & -2.47 & -0.55 & -0.35 & 0.37 & 0.02 & -3.00 \\
\hline Tayland & -0.98 & -1.17 & 0.10 & 0.46 & 0.56 & -1.59 \\
\hline Türkiye & 0.70 & -0.23 & 0.13 & -0.06 & 0.06 & 0.53 \\
\hline Vietnam & 14.21 & -1.15 & 2.77 & -3.45 & -0.67 & 12.38 \\
\hline
\end{tabular}

Kaynak: BACl (2016) verileri kullanılarak yazarlar tarafından hesaplanmıştır.

Tablo 3'te, tarım, balıkçılık ve yiyecek endüstrilerinin basit olarak işlenerek ticarete konu olduğu ürünlerin CMS bulguları yer almaktadır. Bulgulara göre, bu ürünlerde $A B D$, Almanya, Japonya, Güney Kore, İrlanda ve Singapur'un Dünya ticaret paylarında azalmalar görüşmüştür. Diğer ülkelerin ise Dünya ticaret paylarında artışlar görülmüştür. Diğer bir ifade ile, gelişmiş ekonomilerin tarım, balıkçılık ve yiyecek endüstrisi ürünlerinde ticaret payları azalırken, Polonya, Endonezya, Vietnam, Türkiye gibi gelişmekte olan ülkelerin ticaret paylarında artışlar görülmüştür. 1995-2014 yılları arasında, Polonya, Endonezya ve Vietnam'ın Dünya ticaret payındaki değişim \%15 fazla olmuştur. Bu dönemde Türkiye'nin ticaret payı ise \%2,78 artmıştır. Türkiye'nin zaman içerisinde uzmanlaştığı ürünler dünya talebi azalan ürünler olduğu için, MBE ve 
TUE etkileri zayıf kalmış ve bu da ticaret payındaki toplam değişimin RE etkisinden daha küçük olmasına neden olmuştur. Endonezya'nın uzmanlaştığı ürünler ise Türkiye'nin aksine dünyada talebi artan mallar yönünde olmuş, bu sayede yıllık ortalama pay artış oranını \%8,8'den $\% 15,2$ 'ye çıkarabilmiştir. Öte yandan, talebi düşen ürünlerdeki ticaret payını artırmaya devam ettiği için, TUE bileşeni toplam değişimi Polonya'da negatif etkilemiş Vietnam'da ise DUE'den dolayı etkisiz bırakmıştır.

Tablo 3: Kaynak-yoğun Mallar Kategorisinin Tarım, Balıkçılık, Yiyecek-içecek ve Tütün Endüstrilerinde Seçili Ülkelerin CMS Analizi Bulguları, 1995-2014

\begin{tabular}{lcccccc}
\hline Ülke & RE (\%) & MBE (\%) & BUE (\%) & DUE (\%) & TUE (\%) & TD (\%) \\
\hline ABD & -1.48 & -0.05 & -0.12 & 0.53 & 0.40 & -1.13 \\
Almanya & 0.15 & 0.11 & -0.10 & -0.19 & -0.29 & -0.03 \\
Çek Cumhuriyeti & 6.46 & -0.13 & 0.45 & -1.63 & -1.18 & 5.14 \\
Güney Kore & -0.12 & -0.23 & -0.02 & -0.26 & -0.28 & -0.64 \\
İlanda & -2.05 & 0.15 & -0.39 & 0.10 & -0.28 & -2.19 \\
Japonya & -2.40 & 0.05 & -0.58 & 0.48 & -0.09 & -2.44 \\
Polonya & 18.52 & -0.20 & 2.07 & -5.59 & -3.51 & 14.79 \\
Şili & 0.40 & -0.58 & 0.20 & 0.23 & 0.44 & 0.25 \\
Singapur & -0.66 & -0.41 & -0.23 & 0.57 & 0.34 & -0.73 \\
Brezilya & 1.71 & -0.04 & 0.02 & 0.06 & 0.09 & 1.76 \\
Çin & 1.59 & -0.69 & 0.29 & -0.20 & 0.08 & 0.99 \\
Endonezya & 8.86 & 2.96 & 4.37 & -0.99 & 3.38 & 15.21 \\
Filipinler & -0.63 & -0.94 & 0.06 & 0.10 & 0.17 & -1.40 \\
Hindistan & 4.91 & 0.88 & 0.51 & -0.56 & -0.05 & 5.75 \\
Malezya & -1.12 & 3.10 & -1.05 & -0.08 & -1.13 & 0.83 \\
Tayland & -0.00 & 0.66 & 0.15 & -0.16 & -0.00 & 0.65 \\
Türkiye & 3.21 & -0.23 & 0.56 & -0.76 & -0.19 & 2.78 \\
Vietnam & 18.79 & 0.93 & 3.17 & -2.93 & 0.23 & 19.95 \\
\hline Kaynak: BACl & & 0.96 & &
\end{tabular}

Kaynak: BACl (2016) verileri kullanılarak yazarlar tarafından hesaplanmıştır.

Kaynak-yoğun mallar grubundaki kimya, plastik ve ametal mineraller endüstrisindeki CMS bulgularından, İrlanda ve Brezilya dışında tüm gelişmekte olan ekonomilerin hepsinin toplam pazar payını, yani toplam değişimini artırdığını Tablo 4'e bakarak gözlemleyebiliriz. Gelişmiş ülkeler arasında ise yalnızca Güney Kore'nin toplam değişimi pozitiftir ve tüm bileşenler \%1'den düşük düzeydedir. Ve her iki grupta (TD negatif ve pozitif olanlar) bu toplam değişimin en önemli kaynağı RE bileşenidir. Payını artıranlar arasında, Çin, Endonezya, Filipinler, Hindistan, Malezya ve Tayland talebi artan ürünlerde de kendi rekabet edebilirliklerini artırmışlar, ancak bu artış talebi düşen mallarda da gerçekleştiği için bunun net etkisi, yani toplam uyum etki (TUE) zayıf kalmıştır. Vietnam da BUE etkisi daha büyük olduğu için TUE'si oldukça yüksektir. Aynı 
zamanda seçili ülkeler arasında RE değeri en yüksek değere sahip olması, bu ürün gurubunda önümüzdeki dönemde uzmanlaşma derecesinin de hızla artacağının işaretini vermektedir. Türkiye'nin de dâhil olduğu diğer gelişmekte olan ekonomilerde ise Şili dışında MBE ve TUE değerleri düşüktür. Bu ülkenin ticaret kompozisyonu talebi artan mallar yönünde olmasına rağmen, zaman içerisinde söz konusu ürün gurubunda daha da geliştirememiştir.

Tablo 4: Kaynak-yoğun Mallar Kategorisinin Kimya, Kauçuk-plastik ve Ametal Mineraller Endüstrilerinde Seçili Ülkelerin CMS Analizi Bulguları, 1995-2014

\begin{tabular}{|c|c|c|c|c|c|c|}
\hline Ülke & RE (\%) & MBE (\%) & BUE (\%) & DUE (\%) & TUE (\%) & TD (\%) \\
\hline$A B D$ & -1.27 & 0.66 & -0.33 & 0.16 & -0.16 & -0.77 \\
\hline Almanya & -0.84 & -0.16 & -0.17 & 0.24 & 0.06 & -0.94 \\
\hline Çek Cumhuriyeti & 2.74 & -0.70 & 0.17 & -0.35 & -0.17 & 1.86 \\
\hline Güney Kore & 0.41 & 0.33 & 0.37 & -0.01 & 0.35 & 1.10 \\
\hline İrlanda & -2.64 & -0.50 & -0.32 & 0.47 & 0.14 & -3.00 \\
\hline Japonya & -2.18 & -0.27 & -0.05 & 0.62 & 0.56 & -1.89 \\
\hline Polonya & 10.64 & 0.03 & 0.78 & -1.33 & -0.54 & 10.13 \\
\hline Şili & 1.91 & 1.56 & -082 & -0.02 & -0.85 & 2.63 \\
\hline Singapur & -3.38 & 1.36 & -2.06 & 1.51 & -0.55 & -2.56 \\
\hline Brezilya & 0.15 & 0.12 & -0.42 & 0.03 & -0.38 & -0.10 \\
\hline Çin & 26.75 & 0.06 & 2.72 & -4.80 & -2.07 & 24.74 \\
\hline Endonezya & 3.05 & -0.82 & 1.09 & -0.10 & 0.98 & 3.21 \\
\hline Filipinler & 9.94 & 0.01 & 1.32 & -3.96 & -2.64 & 7.31 \\
\hline Hindistan & 13.09 & -0.27 & 1.23 & -7.07 & -5.84 & 6.97 \\
\hline Malezya & 4.85 & -0.21 & 1.49 & -3.27 & -1.77 & 2.85 \\
\hline Tayland & 8.85 & -0.48 & 2.60 & -0.91 & 1.68 & 10.05 \\
\hline Türkiye & 5.19 & -0.28 & 0.11 & -0.79 & -0.67 & 4.22 \\
\hline Vietnam & 210.42 & -0.25 & 38.38 & -20.97 & 17.40 & 227.56 \\
\hline
\end{tabular}

Kaynak: BACI (2016) verileri kullanılarak yazarlar tarafından hesaplanmıştır.

Tablo 5'da yer alan düşük teknoloji yoğunluğuna sahip tekstil, giyim ve deri endüstrilerindeki CMS bulguları, gelişmiş ülkelerin ticaret payını kaybettiklerinin yanı sıra, gelişmekte olan ekonomilerin bazılarında da benzer durumun geçerli olduğunu göstermektedir. Çek Cumhuriyeti, İrlanda, Polonya, Brezilya, Endonezya, Filipinler, Malezya ve Tayland bu grup içerisindeki seçili ülkelere örnek gösterilebilir. Bu durum dünya ticaretinde tekstil endüstrisinin, diğer endüstrilerden farklı olarak belirli bir olgunluğa ulaşması ve ticaret payını artıramaması ile ilişkilendirilebilir. Nitekim MBE bileşenine de baktığımızda yalnızca Vietnam ve Filipinler'de \%1'in biraz üzerinde bir değere sahip olması bu durumu gösteren bir başka örnek olarak sayılabilir. Toplam ticaret payını artıran ülkeler arasında ise, yalnızca Vietnam ticaretini dünya talebi artan mallara yoğunlaştırmış ve uyum sağlayarak ticaret payını başarılı bir şekilde artırabilmiştir. Diğer yan- 
dan, Türkiye, Hindistan, Çin ve Şili'nin payını artırmasının başlıca kaynağı RE olup, diğer bileşenlerin değerleri düşük kalmıştır. Bunlar arasında Çin talebi artan ürünlere doğru payını artırabilmesine rağmen, aynı zamanda talebi düşen mallara doğru da payını artırmış olması toplam değişimine olan katkıyı neredeyse nötrlemiştir. Türkiye'nin, üretim, istihdam ve ihracatı için son derece önemli olan bu sektörde incelenen dönemde pazar payını artırmaya devam etmiştir. Bu artışında neredeyse tamamının RE etkisinden kaynaklandığı söylenebilir. Zira diğer etkilerin toplamı bir şekilde sıfıra eşitlenmiştir.

Tablo 5: Düşük teknolojili Mallar Kategorisinin Tekstil, Giyim Eşyası ve Deri Endüstrilerinde Seçili Ülkelerin CMS Analizi Bulguları, 1995-2014

\begin{tabular}{lcccccc}
\hline Ülke & RE (\%) & MBE (\%) & BUE (\%) & DUE (\%) & TUE (\%) & TD (\%) \\
\hline ABD & -2.52 & 0.36 & -0.92 & 0.34 & -0.58 & -2.74 \\
Almanya & -1.87 & -0.57 & -0.26 & 0.76 & 0.50 & -1.94 \\
Çek Cumhuriyeti & -0.09 & -0.36 & -0.03 & -0.01 & -0.05 & -0.50 \\
Güney Kore & -3.56 & -0.19 & -1.06 & 0.81 & -0.25 & -4.01 \\
İrlanda & -2.31 & 0.60 & -0.78 & 0.18 & -0.60 & -2.30 \\
Japonya & -2.43 & -1.38 & -0.34 & 0.71 & 0.37 & -3.45 \\
Polonya & -1.38 & 0.01 & -0.11 & 0.41 & 0.30 & -1.06 \\
Şili & 1.96 & -0.02 & 0.39 & -0.88 & -0.49 & 1.45 \\
Singapur & -3.07 & 0.64 & -0.90 & 0.58 & -0.32 & -2.74 \\
Brezilya & -3.47 & -0.33 & -0.51 & 0.47 & -0.037 & -3.84 \\
Çin & 4.26 & 0.44 & 1.43 & -0.86 & 0.56 & 5.27 \\
Endonezya & -0.63 & 0.07 & -0.21 & 0.11 & -0.09 & -0.64 \\
Filipinler & -2.43 & 1.05 & -1.17 & -0.60 & -1.77 & -3.16 \\
Hindistan & 3.94 & -0.94 & 0.64 & -1.17 & -0.53 & 2.46 \\
Malezya & -3.30 & 0.76 & -1.36 & 0.58 & -0.77 & -3.32 \\
Tayland & -2.88 & 0.55 & -1.10 & 0.40 & -0.69 & -3.02 \\
Türkiye & 2.39 & 0.34 & 0.54 & -0.89 & -0.35 & 2.38 \\
Vietnam & 39.56 & 1.51 & 12.78 & -4.85 & 7.92 & 49.00 \\
\hline
\end{tabular}

Kaynak: BACI (2016) verileri kullanılarak yazarlar tarafından hesaplanmıştır.

Tablo 6 bu kategorinin ağaç, mobilya ve kâğıt ürünlerindeki CMS bulgularını göstermektedir. Gelişmiş ülkeler konusundaki yukarıdaki bulgularımız (yani toplam değişim bileşeninin negatif oluşu) burada da geçerliliğini korumakla birlikte, Türkiye ile Vietnam'ın yüksek performansı dikkat çekmektedir. Her iki ülke de ticaret payını sırasıyla yılda ortalama olarak \%38,5 ve \%74 artırırken, Türkiye mevcut ürün kompozisyonda dünyada talebi artan mallardaki pozisyonunu koruyarak ve aynı zamanda talebi yüksek mallara da yönelerek bu ürünlerdeki fiyat avantajlarından yararlanabilmiştir. Vietnam ise talebi azalan mallardaki pazar payını daha fazla artırdığından uyum etkisi pazar payındaki gelişimi önemli ölçüde negatif etkilemiştir. Aynı zamanda bu ülkenin mevcut ihracat kompozisyonunun dünya talebi de zaman içerisinde azalmıştır. Bu iki 
bulgu Vietnam'ın söz konusu ürün grubunda fiyat avantajlarından yararlanamamasına yol açabilecektir. Diğer payını artıran ülkelerde toplam değişimi belirleyen başlıca faktör RE'dir. Bununla birlikte, Çin, Çek Cumhuriyeti ve Polonya güçlü bir şekilde dünya pazar payı yükselmekte olan ürünlerde kendi rekabet edebilirliklerini yükseltmelerine karşın, dünya pazar payı düşen ürünlerde rekabet edebilirliğini düşürememiştir. Bu yüzden TD değeri olması gerekenden daha az bir değer almıştır.

Tablo 6: Düşük teknolojili Mallar Kategorisinin Ağaç, Kâğıt, Basım ve Yayın, Mobilya Endüstrilerinde Seçili Ülkelerin CMS Analizi Bulguları, 1995-2014

\begin{tabular}{|c|c|c|c|c|c|c|}
\hline Ülke & RE (\%) & MBE (\%) & BUE (\%) & DUE (\%) & TUE (\%) & TD (\%) \\
\hline$A B D$ & -2.00 & -0.49 & -0.36 & 0.68 & 0.32 & -2.17 \\
\hline Almanya & -1.01 & -0.12 & -0.48 & 0.08 & -0.40 & -1.54 \\
\hline Çek Cumhuriyeti & 7.33 & 0.11 & 2.77 & -1.78 & 0.98 & 8.42 \\
\hline Güney Kore & -2.85 & -0.95 & -0.29 & 0.99 & 0.70 & -3.10 \\
\hline İrlanda & -2.47 & -2.31 & -0.08 & 1.27 & 1.18 & -3.59 \\
\hline Japonya & -2.50 & -0.64 & -0.65 & 0.43 & -0.21 & -3.36 \\
\hline Polonya & 6.85 & 0.27 & 1.32 & -1.36 & -0.03 & 7.09 \\
\hline Şili & -2.82 & 0.10 & -0.63 & 0.42 & -0.20 & -2.93 \\
\hline Singapur & -1.27 & 0.53 & -0.69 & -0.11 & -0.81 & -1.56 \\
\hline Brezilya & -2.14 & 2.10 & -1.98 & 0.05 & -1.92 & -1.97 \\
\hline Çin & 6.85 & -1.01 & 1.57 & -1.26 & 0.31 & 6.15 \\
\hline Endonezya & 0.11 & -0.51 & -0.07 & -0.18 & -0.26 & -0.65 \\
\hline Filipinler & 8.60 & -1.14 & -0.50 & -10.21 & -10.72 & -3.27 \\
\hline Hindistan & 2.96 & 1.39 & 1.01 & -0.09 & 0.91 & 5.27 \\
\hline Malezya & -1.04 & 0.33 & -0.26 & 0.26 & -0.00 & -0.71 \\
\hline Tayland & -2.40 & 1.35 & -1.14 & 0.33 & -0.80 & -1.85 \\
\hline Türkiye & 29.88 & 1.58 & 9.87 & -2.78 & 7.09 & 38.56 \\
\hline Vietnam & 79.45 & -0.68 & 8.41 & -13.10 & -4.68 & 74.08 \\
\hline
\end{tabular}

Kaynak: BACI (2016) verileri kullanılarak yazarlar tarafından hesaplanmıştır.

Orta düzeyde teknoloji yoğunluğuna sahip madencilik, taş ocakçılığı, plastik ve ametal ürünleri için uyguladığımız Tablo 7'deki CMS analizi sonuçlarına göre yalnızca üç ülkenin (ABD, Almanya ve Japonya) payını düşürdüğünü, diğer seçili ülkelerin hepsinin de ticaret payını artırdığını ve bunlar arasında Vietnam'ın yukarıdaki bazı ürün gruplarında olduğu gibi burada da yıllık olarak çok yüksek bir pazar payı büyümesi gerçekleştirdiğini onu Çin ve Türkiye'nin takip ettiğini görebiliriz. Diğer payını artıran ülkelerde İrlanda dışında hiçbir ülkenin mevcut üretim yapısı dünyada ticaret payı artan mallar aracılığıyla kendilerine ticaret payı kazandırmazken Vietnam, Singapur, Polonya ve İrlanda en azından bu mallara doğru bir dönüşüm sağlamışlar ve yılda ortalama \%1'in üzerinde ticaret kazançları elde etmişlerdir. Bu uyum performansını genişletme- 
leri onların pazar paylarını artırmalarında daha yüksek katkı sağlayacaktır. Bunlar dışında, Türkiye, Hindistan ve Çin bu ürünler arasında dünya pazar payı hem düşen hem de yükselen ürünlerde paylarını artırdıklarından, ancak ilki daha fazla olduğundan ticarette \%1'den daha fazla pazar payı kayıpları yaşamışlardır. Diğer ülkelerin TUE bileşenleri \%1'den düşük düzeydedir.

Tablo 7: Orta teknolojili Mallar Kategorisinin Madencilik ve Taş Ocakçılığı, Kimya, Kauçukplastik ve Ametal Mineraller Endüstrilerinde Seçili Ülkelerin CMS Analizi Bulguları, 1995-2014

\begin{tabular}{lrrrrrr}
\hline Ülke & RE (\%) & MBE (\%) & BUE (\%) & DUE (\%) & TUE (\%) & \multicolumn{1}{c}{ TD (\%) } \\
\hline ABD & -1.09 & 0.08 & -0.28 & 0.11 & -0.17 & -1.17 \\
Almanya & -1.25 & -0.11 & -0.20 & 0.26 & 0.05 & -1.31 \\
Çek Cumhuriyeti & 2.80 & 0.10 & 0.28 & -0.42 & -0.13 & 2.78 \\
Güney Kore & 5.15 & -0.00 & 1.32 & -0.93 & 0.39 & 5.54 \\
İlanda & 0.03 & 1.04 & 1.62 & 0.48 & 2.11 & 3.19 \\
Japonya & -1.20 & -0.42 & -0.19 & 0.14 & -0.04 & -1.67 \\
Polonya & 8.18 & -0.46 & 1.98 & -0.60 & 1.37 & 9.10 \\
Şili & 2.55 & 0.92 & 1.02 & -0.61 & 0.41 & 3.89 \\
Singapur & 2.63 & -0.16 & 2.13 & 0.27 & 2.40 & 4.88 \\
Brezilya & -0.05 & -0.20 & 0.02 & 0.31 & 0.34 & 0.08 \\
Çin & 17.12 & -0.38 & 1.74 & -3.76 & -2.02 & 14.71 \\
Endonezya & 3.72 & 0.02 & 0.44 & -0.83 & -0.39 & 3.36 \\
Filipinler & 3.15 & 0.51 & 0.72 & -0.67 & 0.04 & 3.71 \\
Hindistan & 16.01 & -0.82 & 1.98 & -5.00 & -3.01 & 12.17 \\
Malezya & 4.01 & 0.09 & 0.60 & -1.02 & -0.41 & 3.69 \\
Tayland & 8.28 & -0.06 & 1.98 & -1.49 & 0.48 & 8.70 \\
Türkiye & 12.05 & 0.25 & 1.16 & -2.33 & -1.16 & 11.140 \\
Vietnam & 128.20 & 0.29 & 20.43 & -13.71 & 6.71 & 135.20 \\
\hline
\end{tabular}

Kaynak: BACI (2016) verileri kullanılarak yazarlar tarafından hesaplanmıştır.

Tablo 8'deki fabrikasyon metaller ve makine endüstrilerindeki CMS bulgularında, pazar payı kaybedenler arasına Tablo 7'ye ek olarak Brezilya ve İlanda eklenirken, diğer grupta Vietnam, Endonezya ve Çin ticaret paylarını başta RE ve daha sonra TUE aracılığıyla artırabilmiştir. Bununla birlikte, Polonya, Türkiye, Şili ve Çek Cumhuriyeti dünya pazar payı büyüyen hem de küçülen ürünlerde rekabet edebilirliklerini neredeyse aynı ölçüde (\%1'in üzerinde) artırdıklarından bunun net etkisi TUE'nin sıfıra yakın değerler almasına ve dolayısıyla toplam pazar paylarını artıramamalarına yol açmıştır. Bununla beraber, Filipinler'de bu durum ikinci lehine çok daha fazla olduğu için pazar payını yılda ortalama \%20 olumsuz etkilemiştir. Ancak RE bileşeni de \%39 olduğu için TD bileşeninin nihai sonucu \%19,4 olarak elde edilmiştir. MBE bileşenlerine baktığımızda ise tüm seçili ülkelerin değerleri sıfıra yakın olarak hesaplanmıştır. Bu durum bu ürün grubunda seçili ülkelerin ihracat kompozisyonlarının dönem başında ya yeteri kadar talebi artan 
mallara yönelik olmadığını ya da bu ürünlerin ticaret paylarının artık artmadığını göstermektedir. Ancak bazı seçili ülkelerdeki yüksek RE değerleri dikkate alındığında ikinci durumun ihtimali daha ağır basmaktadır.

Tablo 8: Orta teknolojili Mallar Kategorisinin Fabrikasyon Metaller ve Makineler Endüstrilerinde Seçili Ülkelerin CMS Analizi Bulguları, 1995-2014

\begin{tabular}{lrrrrrr}
\hline Ülke & RE (\%) & MBE (\%) & BUE (\%) & DUE (\%) & TUE (\%) & \multicolumn{1}{c}{ TD (\%) } \\
\hline ABD & -1.59 & 0.3461 & -0.4476 & 0.3350 & -0.1126 & -1.3654 \\
Almanya & -0.72 & -0.1244 & -0.3212 & 0.1498 & -0.1713 & -1.0169 \\
Çek Cumhuriyeti & 9.18 & -0.05 & 1.74 & -1.55 & 0.18 & 9.31 \\
Güney Kore & 4.39 & -0.27 & 1.05 & -0.44 & 0.60 & 4.73 \\
İrlanda & -1.66 & 0.45 & -0.02 & 0.16 & 0.14 & -1.06 \\
Japonya & -2.29 & -0.43 & -0.01 & 0.54 & 0.52 & -2.20 \\
Polonya & 15.37 & 0.08 & 2.78 & -2.07 & 0.71 & 16.17 \\
Şili & 6.93 & 0.49 & 1.77 & -1.03 & 0.73 & 8.16 \\
Singapur & 0.10 & 0.23 & 0.59 & -0.15 & 0.44 & 0.77 \\
Brezilya & -0.08 & 0.11 & -0.12 & 0.09 & -0.03 & -0.00 \\
Çin & 32.62 & -0.01 & 8.40 & -6.56 & 1.83 & 34.44 \\
Endonezya & 15.69 & 0.32 & 4.41 & -3.21 & 1.19 & 17.21 \\
Filipinler & 39.47 & 0.45 & 6.57 & -27.07 & -20.49 & 19.42 \\
Hindistan & 23.22 & 0.04 & 3.11 & -4.94 & -1.83 & 21.43 \\
Malezya & 2.39 & 0.81 & 1.47 & -0.56 & 0.91 & 4.12 \\
Tayland & 5.98 & 0.18 & 1.43 & -0.88 & 0.54 & 6.72 \\
Türkiye & 27.05 & 0.13 & 4.17 & -4.98 & -0.81 & 26.37 \\
Vietnam & 127.79 & 0.04 & 52.67 & -22.79 & 29.87 & 157.72 \\
\hline Kaynak: BACl & & & & & & \\
\end{tabular}

Kaynak: BACl (2016) verileri kullanılarak yazarlar tarafından hesaplanmıştır.

Tablo 9'a göre büyük bir çoğunluğu orta teknoloji kategorisinde yer alan ulaşım sektörü ürünlerinde seçili ülkelerin beş tanesinin ( $A B D$, , İrlanda, Japonya, Singapur ve Malezya) toplam pazar payları incelenen dönemde küçülmüştür. Almanya yukarıdaki birçok ürün guruplarından farklı olarak burada hafif de olsa payını artırmıştır. Payını artıranlar arasında, Çek Cumhuriyeti, Çin ve Türkiye payı artan ürünlerde uzmanlaşmıştır. Ancak bu ülkeler pazar paylarını dünyada talebi yükselen ürünlere doğru artırmalarına rağmen, mal bileşimleri ağırlıklı olarak halen talebi düşen mallardadır. Uyum performansını daha da artırmaları halinde MBE etkisi de artacak ve TD’ye daha yüksek katkılar sağlayacaktır. Aynı zamanda dünya talebi düşen mallarda da rekabet edebilirliklerini artırmak yerine azaltmaları da diğer dönemlerde MBE'yi pozitif etkileyebilecektir. Bu anlamda Endonezya'nın ağırlıklı mal bileşimi dünyada talebi yükselen mallardayken, ancak talebi düşen mallarda da payını yükseltme eğiliminde olduğu için, dış ticaret trendlerine uyum sağlayamamaktadır. Buna rağmen RE'nin oldukça yüksek olması nihai değişimi pozitif etkilemiştir. Son olarak, Filipinler, Hindistan, Malezya, Tayland ve en yüksek pazar payı artıran 
Vietnam önemli ölçüde payı azalan ürünlerde uzmanlaşmıştır ve MBE bileşenleri de düşük düzeydedir.

Tablo 9: Orta teknolojili Mallar Kategorisinin Otomotiv, Demiryolları ve Gemicilik Ekipmanları Endüstrilerinde Seçili Ülkelerin CMS Analizi Bulguları, 1995-2014

\begin{tabular}{|c|c|c|c|c|c|c|}
\hline Ülke & RE (\%) & MBE (\%) & BUE (\%) & DUE (\%) & TUE (\%) & TD (\%) \\
\hline ABD & -0.8340 & 0.1938 & -0.2355 & 0.0474 & -0.1882 & -0.8283 \\
\hline Almanya & 0.0152 & -0.0048 & 0.2184 & 0.0878 & 0.3062 & 0.3166 \\
\hline Çek Cumhuriyeti & 23.50 & -0.03 & 5.17 & -3.72 & 1.45 & 24.92 \\
\hline Güney Kore & 7.61 & -0.63 & 1.89 & -1.43 & 0.45 & 7.43 \\
\hline İrlanda & -1.73 & -0.05 & -0.26 & 0.30 & 0.04 & -1.75 \\
\hline Japonya & -2.19 & -0.27 & -0.42 & 0.39 & -0.02 & -2.49 \\
\hline Polonya & 20.22 & 0.56 & 3.58 & -3.50 & 0.07 & 20.86 \\
\hline Şili & 2.99 & 0.27 & 1.10 & -0.43 & 0.67 & 3.94 \\
\hline Singapur & -1.06 & 2.65 & -2.03 & -0.02 & -2.06 & -0.47 \\
\hline Brezilya & 0.68 & 0.71 & -0.05 & -0.58 & -0.64 & 0.76 \\
\hline Çin & 43.58 & 0.66 & 7.86 & -6.55 & 1.30 & 45.55 \\
\hline Endonezya & 22.02 & 2.53 & 1.62 & -5.15 & -3.52 & 21.03 \\
\hline Filipinler & 26.26 & -0.08 & 0.74 & -17.70 & -16.95 & 9.22 \\
\hline Hindistan & 21.79 & 0.28 & 3.58 & -4.61 & -1.02 & 21.06 \\
\hline Malezya & -0.43 & 2.32 & -2.18 & -0.20 & -2.38 & -0.50 \\
\hline Tayland & 55.50 & 0.33 & 8.27 & -10.42 & -2.14 & 53.69 \\
\hline Türkiye & 32.22 & 0.10 & 8.12 & -4.83 & 3.29 & 35.62 \\
\hline Vietnam & 178.68 & 0.09 & 12.31 & -23.72 & -11.41 & 167.37 \\
\hline
\end{tabular}

Kaynak: BACI (2016) verileri kullanılarak yazarlar tarafından hesaplanmıştır.

Tablo 10'daki ilaç endüstrisinde ise seçili ülkeler arasında yalnızca dört ülkenin dünya ticaretindeki pazar payları azalırken, diğerleri farklı boyutlarda artırmıştır. TUE yoluyla \%1'in üzerinde pazar payını artıran ülkeler İrlanda ve Singapur'dur. Bu ürün grubunda, dünya ticaret payını artıran ülkeler arasında özellikle Asya'dan Vietnam, Hindistan ve Singapur ile Doğu Avrupa'dan Polonya ve Çek Cumhuriyeti dikkati çekmektedir. Bu endüstride Türkiye'nin performansı da dikkat çekmektedir. Zira 1995-2014 döneminde Türkiye bu sektördeki ticaret payını ortalama yılık \%6.15 artırmıştır. Aslında bu daha fazla olabilirdi, fakat MBE bu dönemde oldukça yüksek bir oranda negatif gerçekleşmiştir. Türkiye'ye benzer bir şekilde Polonya, Brezilya ve Hindistan dünya talebi artan ürünlerde rekabet edebilirliklerini de artırarak toplam değişimi \%1'in üzerinde pozitif etkileyebilecekken, yukarıda benzer durumdaki bir çok ülkede olduğu gibi talebi düşen pazarlardan başarılı bir şekilde çıkamadığı için toplam değişimi bundan negatif etkilenmiş̧ir. Diğer yandan, MBE'nin toplam değişime katkısı birçok ülkede negatiftir. Bu durumda seçili ekonomiler uyum performanslarını artırarak MBE'deki negatif durumun etkisini ortadan kaldırabilirler. 
Tablo 10: Yüksek teknolojili Mallar Kategorisinin Ilaç Sanayii Endüstrilerinde Seçili Ülkelerin CMS Analizi Bulguları, 1995-2014

\begin{tabular}{lrrrrrr}
\hline Ülke & RE (\%) & MBE (\%) & BUE (\%) & DUE (\%) & TUE (\%) & TD (\%) \\
\hline ABD & 0.29 & 1.25 & -1.01 & 0.28 & -0.72 & 0.82 \\
Almanya & -0.61 & 0.12 & 0.20 & 0.40 & 0.61 & 0.12 \\
Çek Cumhuriyeti & 7.65 & -0.63 & 0.96 & -2.54 & -1.58 & 5.44 \\
Güney Kore & 3.95 & -1.98 & 0.44 & -2.58 & -2.14 & -0.16 \\
İlanda & 2.43 & -0.28 & 1.60 & 0.09 & 1.70 & 3.85 \\
Japonya & -2.91 & -1.96 & -0.23 & 1.63 & 1.40 & -3.47 \\
Polonya & 5.28 & 0.19 & 1.12 & -0.54 & 0.57 & 6.06 \\
Şili & 1.25 & 0.18 & 0.06 & -0.45 & -0.38 & 1.04 \\
Singapur & 7.41 & -2.08 & 3.38 & -1.11 & 2.26 & 7.58 \\
Brezilya & 3.80 & -1.64 & 1.19 & -0.34 & 0.85 & 3.00 \\
Çin & 14.57 & -3.00 & 0.16 & -10.75 & -10.58 & 0.97 \\
Endonezya & 3.56 & -0.76 & 0.72 & -1.54 & -0.82 & 1.97 \\
Filipinler & -0.82 & -0.19 & -0.20 & -0.10 & -0.30 & -1.31 \\
Hindistan & 15.93 & -1.84 & 2.24 & -5.72 & -3.48 & 10.60 \\
Malezya & 0.82 & -0.84 & -0.23 & -1.33 & -1.56 & -1.59 \\
Tayland & 1.18 & -1.74 & -0.08 & -1.10 & -1.18 & -1.75 \\
Türkiye & 7.36 & -1.36 & 1.83 & -1.67 & 0.15 & 6.15 \\
Vietnam & 87.04 & -0.76 & 7.90 & -30.65 & -22.75 & 63.52 \\
\hline & & & & & &
\end{tabular}

Kaynak: BACI (2016) verileri kullanılarak yazarlar tarafından hesaplanmıştır.

Yüksek teknoloji yoğunluğuna sahip iletişim, medikal ve optik araçlar endüstrisi ürünlerinde $A B D$, Almanya, Japonya ve Singapur gibi yüksek gelirli ülkelerin Dünya ticaretindeki pazar paylarının küçüldüğü Tablo 11'de görülmektedir. Ancak yukarıdaki ürün gruplarında olduğu gibi, gelişmekte olan her ülke burada toplam pazar payını artırmamıştır. Bununla birlikte, payını artıranlar arasında Vietnam oldukça yüksek düzeyde büyüme sağlamış ve bununda nerdeyse yarısını BUE etkisi aracılıyla gerçekleştirmiştir. Öte yandan \%1'in üzerinde TUE etkisi aracılı̆̆ıyla pazar payını artıran diğer ülkeler Çin, Polonya ve Malezya ve Güney Kore'dir. Şili, Endonezya, Filipinler ve Hindistan'ın DUE değerleri büyük olduğundan toplam değişimi olumsuz etkilemiştir. Güney Kore, Japonya, Hindistan ve Türkiye dışında kalan diğer seçili ülkeler MBE'den \%1'den daha fazla oranda olumsuz etkilenirken, TUE zayıf kalmıştır. Türkiye'nin çoğunlukla kendi çabalarından kaynaklanan RE dolayısıyla elde ettiği yıllık ortalama \%7,9 olan pazar büyümesi, talebi yükselen ürünlerde uzmanlaşma sağlanarak, tıpkı Vietnam'ın durumunda olduğu gibi, artırılabilir. 
Eskişehir Osmangazi Üniversitesi iiBF Dergisi

Tablo 11: Yüksek teknolojili Mallar Kategorisinin Iletişim, Medikal, Ölçüm ve Optik Araçlar Endüstrilerinde Seçili Ülkelerin CMS Analizi Bulguları, 1995-2014

\begin{tabular}{lrrrrrr}
\hline Ülke & RE (\%) & MBE (\%) & BUE (\%) & DUE (\%) & TUE (\%) & \multicolumn{1}{c}{ TD (\%) } \\
\hline ABD & -2.05 & 1.08 & -1.45 & 0.38 & -1.07 & -2.04 \\
Almanya & -0.91 & 0.68 & -1.09 & 0.05 & -1.03 & -1.26 \\
Çek Cumhuriyeti & 20.99 & -1.21 & 7.66 & -6.84 & 0.81 & 20.60 \\
Güney Kore & 1.32 & -0.78 & 2.67 & 0.70 & 3.37 & 3.91 \\
İrlanda & -0.40 & 2.71 & -0.36 & -0.02 & -0.39 & 1.92 \\
Japonya & -3.25 & -0.50 & -1.37 & 1.62 & 0.25 & -3.50 \\
Polonya & 23.15 & -1.71 & 9.95 & -2.70 & 7.24 & 28.69 \\
Şili & 11.41 & 0.67 & 2.25 & -7.57 & -5.32 & 6.76 \\
Singapur & -1.86 & -1.66 & -0.04 & 0.98 & 0.93 & -2.58 \\
Brezilya & -1.84 & -1.92 & -0.05 & 1.48 & 1.43 & -2.34 \\
Çin & 20.41 & -1.19 & 11.03 & -7.67 & 3.36 & 22.58 \\
Endonezya & 3.63 & -1.47 & -0.14 & -2.99 & -3.14 & -0.98 \\
Filipinler & 5.04 & 0.70 & -1.12 & -3.57 & -4.70 & 1.05 \\
Hindistan & 17.19 & -0.99 & 4.10 & -7.38 & -3.28 & 12.91 \\
Malezya & -1.70 & -1.49 & -0.03 & 1.08 & 1.04 & -2.14 \\
Tayland & 2.26 & -0.46 & -0.07 & -1.47 & -1.55 & 0.24 \\
Türkiye & 7.77 & -0.03 & 0.87 & -0.69 & 0.17 & 7.91 \\
Vietnam & 776.36 & -1.78 & 789.04 & -144.94 & 644.09 & 1418.67 \\
\hline Kaynak: BAC1 & & & & & &
\end{tabular}

Kaynak: BACl (2016) verileri kullanılarak yazarlar tarafından hesaplanmıştır.

Yukarıdaki bulgularımızı özetleyecek olursak, ilk olarak, seçili ülkeler arasında yüksek gelirli ülkelerin pazar paylarını birçok endüstride kaybettiğini söyleyebiliriz. Nitekim ABD ve Japonya yukarıdaki endüstriler arasında on, Almanya dokuz, bu ülkelere göre daha geç endüstrileşen Singapur ve Güney Kore sırasıyla yedi ve altı endüstride pazar paylarını kaybetmişleridir. Bu kayıpların büyük bir çoğunluğu rekabet edebilirlik etkisinden kaynaklanmaktadır. İkinci olarak, gelişmiş ekonomiler dışındakilerin birçoğu, yukarıdaki ürün gruplarının çoğunda, pazar paylarını farklı boyutlarda artırmışlardır. Bu artışın önemli bir kısmında yine rekabet edebilirlik etkisin belirleyici rolü bulunmaktadır. Bu iki bulgu, literatürdeki "üretim süreçlerinin coğrafi olarak ayrı bölgelere ayrılması" (Krugman ve diğerleri, 1995: 332) olarak tanımlanan "ürün parçalanması" kavramı ile açıklanabilir. Bu kavram üzerine literatürde yapılan çalışmalarda, üretim maliyetlerindeki ülkeler arasındaki farklılıkların uluslararası ticarette önemli bir faktör olduğu ve düşük maliyet yapısına sahip ekonomilerin, merkezi gelişmiş ülkelerdeki çok uluslu firmalarının üretim süreçlerine katılmalarının kendilerine kazançlar sağlayacağı iddia edilmektedir (Cantwell, 1994; Jones, 2000, Baldwin, 2001; Athukorala, 2005). Bununla beraber yukarıdaki bulgunun, geliş- 
mekte olan ülkeler cephesinde bazı istisnaları bulunmaktadır. Örneğin, Filipinler, Malezya, Brezilya ve Tayland düşük ve orta teknolojili ürünlerde, İrlanda, Singapur, Endonezya, Malezya ve Tayland da birincil ve kaynak yoğun ürünlerde pazar paylarını düşürmüşlerdir.

Yürüttüğümüz analiz ile ilgili olarak paylaşmamız gereken bir diğer bulgu ise, rekabet edebilirlik etkisi dışında, gelişmekte olan ülkelerin ticaret kompozisyonlarını dünyada talebi değişen ürünlere doğru kaydırarak, uyum sağlama potansiyeli bakımından önemli ölçüde ayrıştığıdır. Özellikle orta ve yüksek teknolojili endüstriler arasında en hızlı biçimde pazar payını artıran ekonomiler arasında bile, birçok ülke ürün kompozisyonunu dünyada talebi artan ürünlere doğru kaydıramamakta ve dolayısıyla piyasalara uyum sağlayamamaktadır. Yine bu ülkeler, uyum performansı konusunda, yükselen ürünlerde kendi rekabet edebilirliklerini artırsalar dahi, ürün kompozisyonlarında talebi düşen ürünlerinin ağırlığından dolayı, bu durum uyum performansının toplam pazar payı değişimine etkisi negatif olmaktadır. Türkiye'nin orta teknolojili endüstrilerdeki durumu bunun tipik bir örneğidir. Özellikle 2000'lerden sonra bu endüstrilerdeki toplam ihracat payını önemli ölçüde yükseltmesine rağmen, ağırlığını otomotiv endüstrisi dışında bu kategorideki yükselen ürünlere verememiş ve fiyat avantajlarından da yararlanamamıştır. Bu bakımdan, ele aldığımız ülkeler içerisinde Vietnam'ın -ve bir dereceye kadar da Çin'in- düşük, orta ve yüksek teknolojili endüstrilerdeki performansı dikkat çekmektedir. Nitekim ilk kısımdaki betimsel analizlerde de bu ülkeler toplam ihracat cinsinden, diğer yüksek ihracat düzeyine sahip ülkelere doğru yüksek bir yakınsama performansı göstermişlerdir.

\section{Sonuç}

Giriş bölümünde rekabet edebilirliği, sürdürülebilir büyümeyi endüstriyel faaliyetler aracıllğıyla sağlayan, nispi süreç olarak tanımlamıştık. Bu sürdürülebilir büyümenin sağlanması için de, -özellikle gelişmekte olan- ekonomilerin uzmanlaşma kalıplarını dünyadaki ürünlerin talep trendlerine uygun olarak değiştirmeleri gerekmektedir. Bunun gerçekleşip gerçekleşmediğini veya ne derece gerçekleştiğini görebilmek için, bu çalışmada seçili on sekiz ülkenin, farklı teknoloji yoğunluklarına sahip alt endüstrilerinin ticaret performanslarını, dünya ticaret paylarını göz önünde bulundurarak sabit pazar payı analizinden faydalanarak inceledik.

Elde ettiğimiz bulgular, düşük, orta ve yüksek teknolojili endüstrilerde birçok az gelişmiş ve gelişmekte olan ülkenin pazar paylarını, kendi çabaları, yani rekabet edebilirlik etkisi yoluyla hızlı bir biçimde artırdıklarını göstermektedir. ABD, Japonya ve Almanya başta olmak üzere, yüksek gelirli ülkelerin pazar paylarının ya azalmakta ya da durağan bir konumda olduğunu tespit ettik. Bu iki bulguya literatürde "ürün parçalanması" kavramı ile açıklama getirdik. Küresel ekonomide üretim süreçlerinin kaydırılması genel olarak ABD, Japonya ve Almanya'nın çok uluslu firmalarının Asya ülkelerine yabancı yatırımları veya bu firmaların-özellikle son yıllarda- bu ülkelerdeki yerel firmalarla yaptıkları anlaşmalar aracılılı̆̆ıla gerçekleşmektedir (Athukorala, 2005: 1-6). 1960'lı yılların sonlarında, elektronik ve tekstil sektöründe başlayan bu süreç daha sonra üretim teknolojisinin emek yoğun segmentlerine ayrılmasına izin verdiği diğer tüm sektörlere yayılmıştır. Elektrikli aletler, otomobil parçaları, elektrikli makine ve optik ürünleri, müzik aletleri, saatler ve kameralar bu genişleyen sektörlere örnek olarak gösterilebilir. Nitekim bu sektörlerin Lall (2000)'in sınıflamasında ihtiva edildiği orta veya yüksek teknoloji yoğunluklu mallar kategorisi burada ele aldığımız Asya ekonomilerinin (son dönemlerde Hindistan ve Vietnam da olmak üzere) toplam ihracatında yüksek paylara sahiptir. Bununla beraber, Brezilya, İrlanda, Filipinler ve Tayland gibi ekonomilerin küresel değer zincirlerinin yoğun olduğu bu gruplarda pazar paylarını düşürmesi, sektör-spesifik sanayi politikalarının sorgulanması gereğine işaret etmektedir. 
Öte yandan, rekabet edebilirlik etkisi dışında, ülkelerin dünya talebine uyum performansları, diğer ülkeleri de analize dâhil ettiğimizde, birbirlerinden farklılaşmaktadır. Buradan, Türkiye ve benzer gelişmişlik düzeyindeki ülkelerin ihracatta daha başarılı olabilmesi için, ihracatta son dönemlerde başarılı olan Çin ve Vietnam'a benzer şekilde, Taymaz ve diğerlerinin (2011: 91-92) de öne sürdüğü gibi, ticaretten yüksek gelir elde edebilmesi bakımından uluslararası üretim zincirleri ile olan bağlantısını en az orta düzey teknolojili endüstriler kadar yüksek teknolojili endüstrilerle de kurmasını ve aynı zamanda mevcut bağlantıların da dünya ticaretindeki eğilimlere uyumlu bir biçimde değiştirmesi gerektiğini önerebiliriz. Gelecek çalışmalar, bu uyumun küresel değer zincirleri ve yaşam standartlarının en önemli göstergesi olan üretkenlik ile olan bağının araştırılmasına yönelecektir. 


\section{Kaynaklar}

Athukorala, P. (2005). Product fragmentation and trade patterns in East Asia. Asian Economic Papers, 4 (3), 1-27.

Baldwin R. E., (1958). The Commodity composition of trade: Selected industrial countries, 1900-1954. The Review of Economics and Statistics, 40 (1), 50-68.

Baldwin, R. E. (2001). The implications of increasing fragmentation and globalization for the World Trade Organization.

L. K. Cheng and H. Kierzkowski (Eds) içinde, Global production and trade in East Asia (s. 249-71). Boston: Kluwer Academic Publishers.

Banerji, R. (1974). The export performance of less developed countries: a constant market share analysis. Weltwirtschaftliches Archiv, 110, 447-481.

Bowen, H. P. and Pelzman, J. (1984). US export competitiveness: 1962-77. Applied Economics, 16 (3), 461-473.

Cantwell, J. (1994). The relationship between international trade and international production. D. Greenway and L. A. Winters (Eds.) içinde, Survey in International Trade, (s. 303-28). Oxford: Basil Blackwell.

Erlat, G., ve Erlat, H. (2012). Türkiye'nin orta doğu ülkeleri ile olan ticareti, 1990-2012. Tartışma Metni 2012/26, Türkiye Ekonomi Kurumu, Ankara.

Fagerberg, J. and Sollie, S. (1987). The method of constant market shares analysis reconsidered. Applied Economics, 19 (12), 1571-1583.

Gauiler, G. and Zignango, S. (2010). BACl: International Trade Database at the Product-Level. The 1994-2007 Version. CEPII Working Paper 2010-23

Jones, R. W. Globalization and the theory of input trade. Cambridge: MIT Press.

Klasra, M. A. and Fidan, H. (2007). Competitiveness of major exporting countries and Turkey in the world fishery market: A constant market share analysis. Aquaculture Economics \& Management, 9 (3), 125-138.

Kotan, Z. (2000). Export performance of Turkey in the European Union market compared to the South Easian countries. Yayınlanmamış Yüksek Lisans Tezi, METU, Department of Economics, Ankara.

Krugman, P., Cooper, R. N. and Srinivasan, T. N. (1995). Growing world trade: Causes and consequences. Brooking Papers on Economic Activity, 1995 (1), 327-377.

Lall, S. (2000). The technological structure and performance of developing country manufactured exports, 1985-98. Oxford Development Studies, 28 (3), 213-243.

Lall, S. (2001a). Competitiveness indices and developing countries: an economic evaulation of the Global Competitiveness Report. World Development, 29 (9), 1501-1525.

Lall, S. (2001b). Competitiveness, technology and skills. Cheltenham: Edward Elgar.

Laursen, K. (1999). The impact of technological opportunity on the dynamics of trade performance. Structural Change and Economic Dynamics, 10 (3-4), 341-357.

Leamer, E. E. and Stern, R. M. (1970). Quantitative international economics. Boston: Allyn and Bacon.

Lohrmann, A.-M. (2000). On Turkey's export performance: a decomposed constant market shares analysis. Russian and East European Finance and Trade, 36 (4), 80-90.

Merkies, A. Q. and Meer, T. (1988). A theoretical foundation for constant market share analysis. Empirical Economics, $13(2), 65-80$.

OECD. (1992). Technology and the economy: the key relationships. Paris: Organisation for Economic Co-operation and Development.

OECD. (1996). Industrial competitiveness. Paris: OECD.

Ongun, Ş. E. (1990). Turkey's fresh fruit and vegetable exports to the European Community: a constant market shares analysis. Yayınlanmamış Yüksek Lisans Tezi, METU, Department of Economics, Ankara.

Porter, M. E. (1990). The competitive advantage of nations. New York: Free Press.

Richardson, J. D. (1971a). Constant-market shares analysis of export growth. Journal of International Economics, 1 (2), 227-239.

Richardson, J. D. (1971b). Some senstivity tests for a "constant-market-shares" analysis of export growth. The Review of Economics and Statistics, 53 (3), 300-304.

Spiegelglas, S. (1959). World exports of manufactures, 1957 vs. 1937. Manchester School of Economic and Social Studies, 27 (2), 111-139. 
Eskişehir Osmangazi Üniversitesi iiBF Dergisi

Şahan, F. (2012). The impact of technology level and structural change of exports on the dynamics of international competitiveness: a sectoral disaggregated analysis of turkish manufacturing sector. Yayınlanmış Doktora Tezi, Middle East Technical University, The Department of Economics, Ankara.

Tatarer, Ö. (2004). The export performance of the Turkish manufacturing industries with respect to selected countries. Yüksek Lisans Tezi, METU, Department of Economics.

Taymaz, E., Voyvoda, E. ve Yılmaz, K. (2011). Uluslararası üretim zincirlerinde dönüşüm ve Türkiye'nin konumu. TÜSiAD Yayın no:No: T/2011,12; 522, TÜSiAD-Koç Üniversitesi, Ekonomik Araştırma Forumu, İstanbul.

Temiz, D. (2002). Turkey's agricultural exports (1989-1998): constant market shares analysis. Yayınlanmamış Yüksek Lisans Tezi, METU, Department of Economics, Ankara.

Tyszynski, H. (1951). World trade in manufactured commodities, 1899-1950. The Manchester School, 19 (3), 272-304. 